Journal of Advanced Research in Fluid Mechanics and Thermal Sciences

\title{
The Data Mining Technique Using RapidMiner Software for New Zeotropic Refrigerant
}

\author{
Piyanut Saengsikhiao ${ }^{1}$, Juntakan Taweekun ${ }^{2, *}$ \\ Energy Technology Program, Faculty of Engineering, Prince of Songkla University, Hat Yai, Songkhla 90112, Thailand \\ 2 Department of Mechanical Engineering, Faculty of Engineering, Prince of Songkla University, Hat Yai, Songkhla 90112, Thailand
}

\section{ARTICLE INFO ABSTRACT}

Article history:

Received 27 August 2020

Received in revised form 28 March 2021

Accepted 5 April 2021

Available online 22 May 2021

\section{Keywords:}

Refrigerant; refrigeration system; energy efficiency; environmentally friendly; data mining

\begin{abstract}
This research presents the development of environmentally-friendly and energy efficient refrigerant for medium temperature refrigeration systems that new azeotropic refrigerant mixture of hydrofluorocarbons and hydrocarbon that can retrofit in the refrigeration system using R404A. The medium back pressure refrigeration testing standard that follow CAN/ANSI/AHRI540 standard airconditioning, heating, and refrigeration institute (AHRI) and The properties of refrigerants and refrigeration simulation system that used national institute of standards and technology (NIST) reference fluid thermodynamic and transport properties database (REFPROP) software and NIST vapor compression cycle model accounting for refrigerant thermodynamic and transport properties (CYCLE_D-HX) software. The methodology uses decision tree function in datamining by rapid minor software that first of KDnuggets annual software poll that showed new azeotropic refrigerant mixture had cooling capacity, refrigerant effect, GWP and boiling point were lower than R404A but work and pressure for medium temperature refrigeration system of azeotropic refrigerant mixture were higher than R404A. The artificial intelligence (Al) by data mining technic can predictive environmentally-friendly and energy efficient refrigerant for medium temperature refrigeration. The result of refrigerant mixed by R134A, R32, R125 and R1270 and is consistent with the evolution of fourth-generation refrigerants that contain a mixture of HFCs and HCs which are required to produce a low-GWP, zero-ozone-depletion-potential (ODP), high-capacity, low-operating-pressure, and nontoxic refrigerant.
\end{abstract}

\section{Introduction}

Energy use in Thailand's business sector has been ranked second among overall energy users in the country and has thus been targeted for energy-saving options [1]. The number of convenience stores in Thailand was more than 20,000 in 2019, and this number continuously increases on an annual basis [2]. The majority are open 24 hours per day and, consequently, the retail sector is the fourth largest consumer of energy in the business sector, consuming more energy than residences [3]. The components that contribute to the energy consumption of convenience stores in Thailand,

\footnotetext{
* Corresponding author.

E-mail address: jantakan.t@psu.ac.th; juntakan2016@gmail.com
}

https://doi.org/10.37934/arfmts.83.1.7090 
ranked from highest to lowest, are refrigeration systems, air-conditioning systems, electrical equipment, and lighting $[4,5]$. The proportions of energy use in convenience stores in Taiwan have been previously ranked, as shown in Figure 1 below [6].

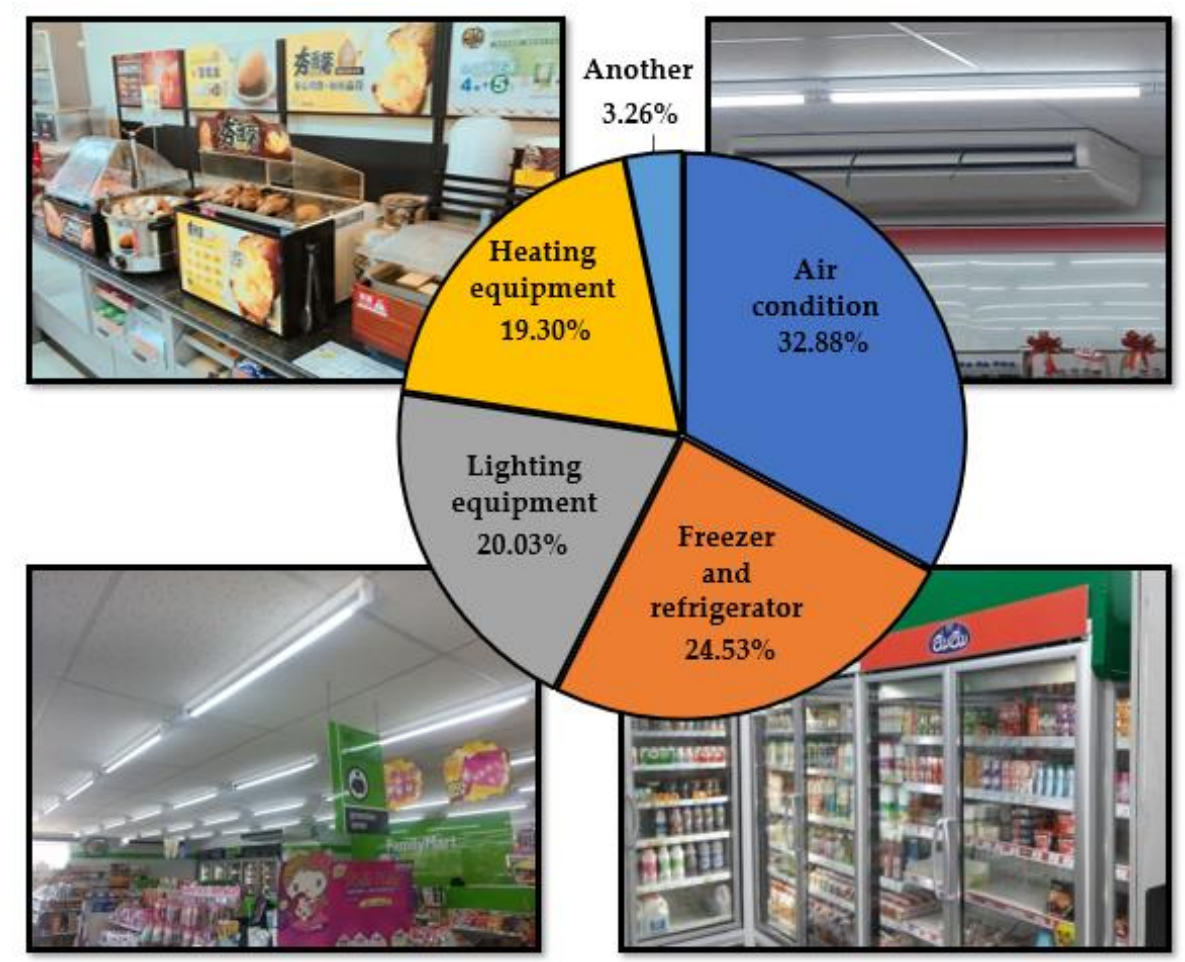

Fig. 1. Proportions of energy use in Taiwanese convenience stores [6]

The best options for reducing energy consumption in convenience stores in Thailand are high energy efficiency and an efficient energy-management system. A good example of energy savings in refrigeration systems is shown in Figure 2 below [7]. Energy savings in refrigeration systems can be achieved through decreased power consumption of the compressor, as this it is the component that utilizes the most energy.

Refrigerant trends in Thailand have shown improvements through increased energy efficiency and decreased global warming potential (GWP), as shown in Figure 3 [8,9], which is related to the hydrofluorocarbon (HFCs) phase-down schedule, as shown in Figure 4 [10]. First- and secondgeneration refrigerants are composed of natural refrigerants and hydrocarbons (HCs), both of which do not impact the environment, have low GWP, and have zero ozone-depletion potential (ODP) [1113]. R744 operates under high pressure and is highly toxic and flammable [14-16]. Following the second generation, third-generation refrigerants are composed of chlorofluorocarbons (CFCs) [1719] and hydrochlorofluorocarbons (HCFCs) [20-22], which are easy to use, can operate under low pressure, and are non-toxic. However, they have high GWP and ODP, contributing to ozone depletion and global warming. Therefore, in the development of refrigerants, significantly decreased ODP and GWP are highly desirable. Moreover, third-generation refrigerants (i.e., CFCs and HCFCs) were further developed into hydrofluorocarbon (HFCs) refrigerants that possessed low GWP and zero ODP [23-25]. Fourth-generation refrigerants are mainly hydrofluoroolefins (HFOs) with low GWP and low capacity [26-28]. These refrigerants are generally a mixture of HFCs [29-31], HFOs [32-34], and HCs [35-37]. Natural refrigerants are low-GWP, zero ODP, high-capacity, low-pressure, and non-toxic [38-40]. 


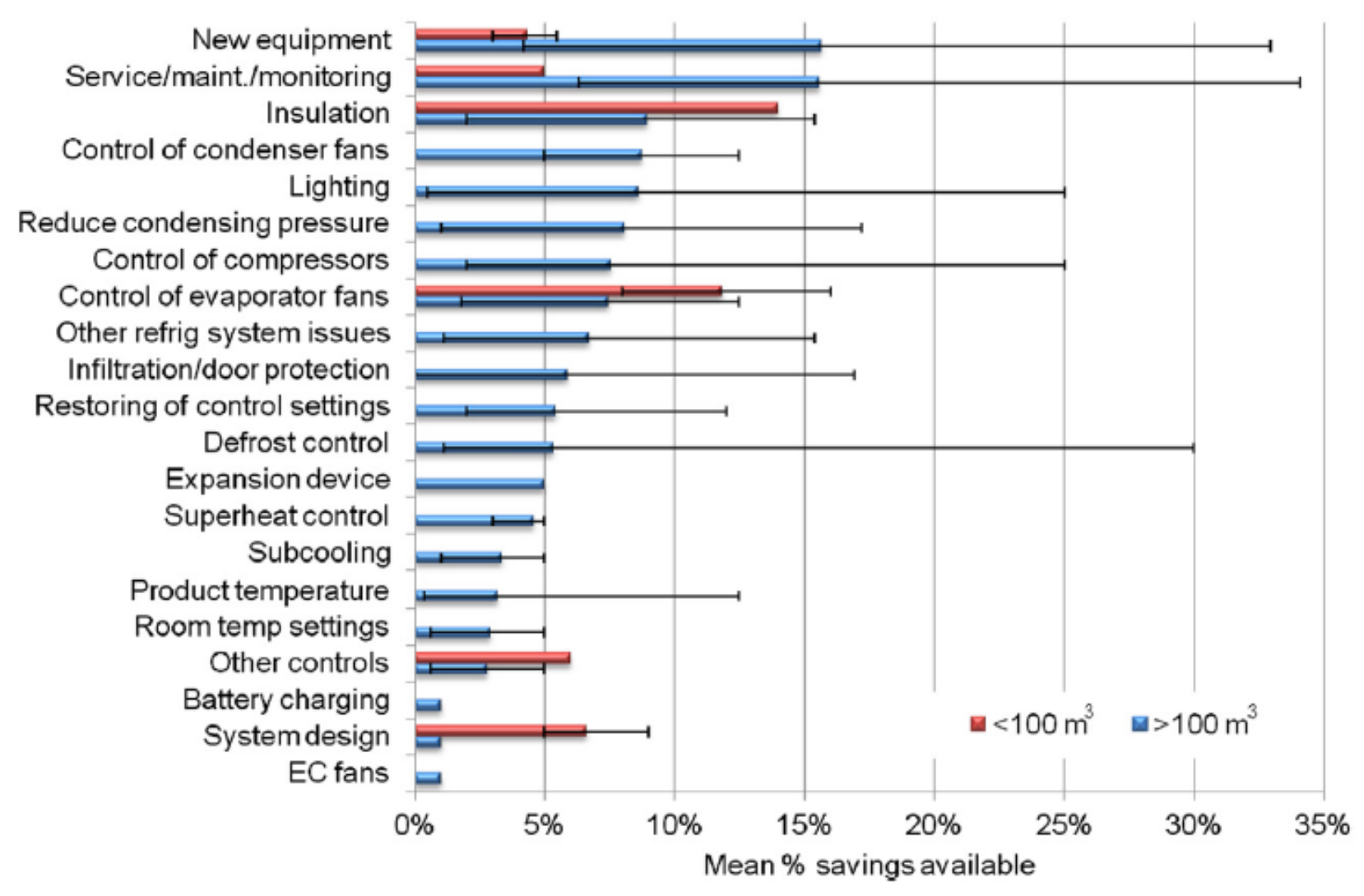

Fig. 2. Examples of energy savings in refrigeration systems [7]

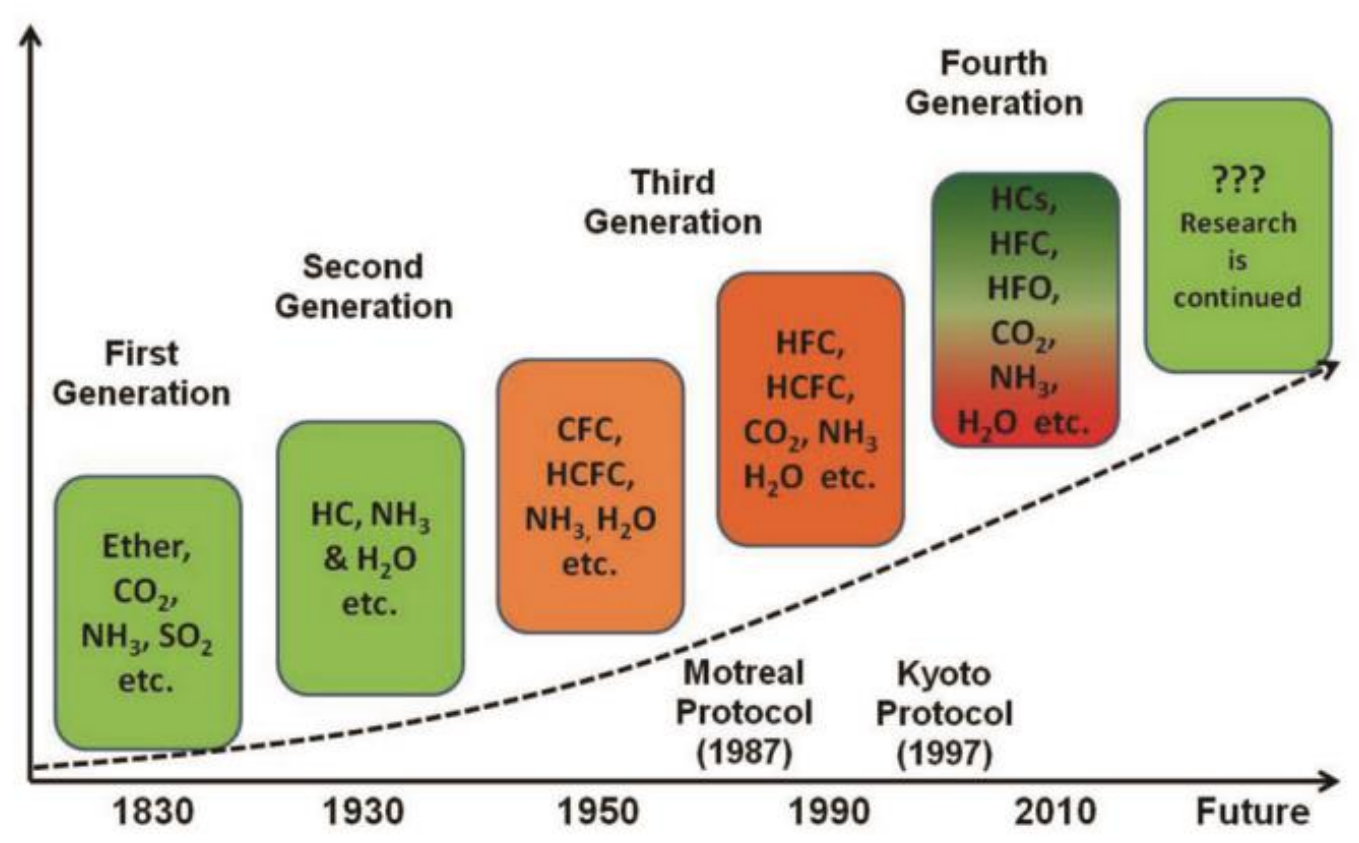

Fig. 3. Evolution of refrigerants $[8,9]$ 


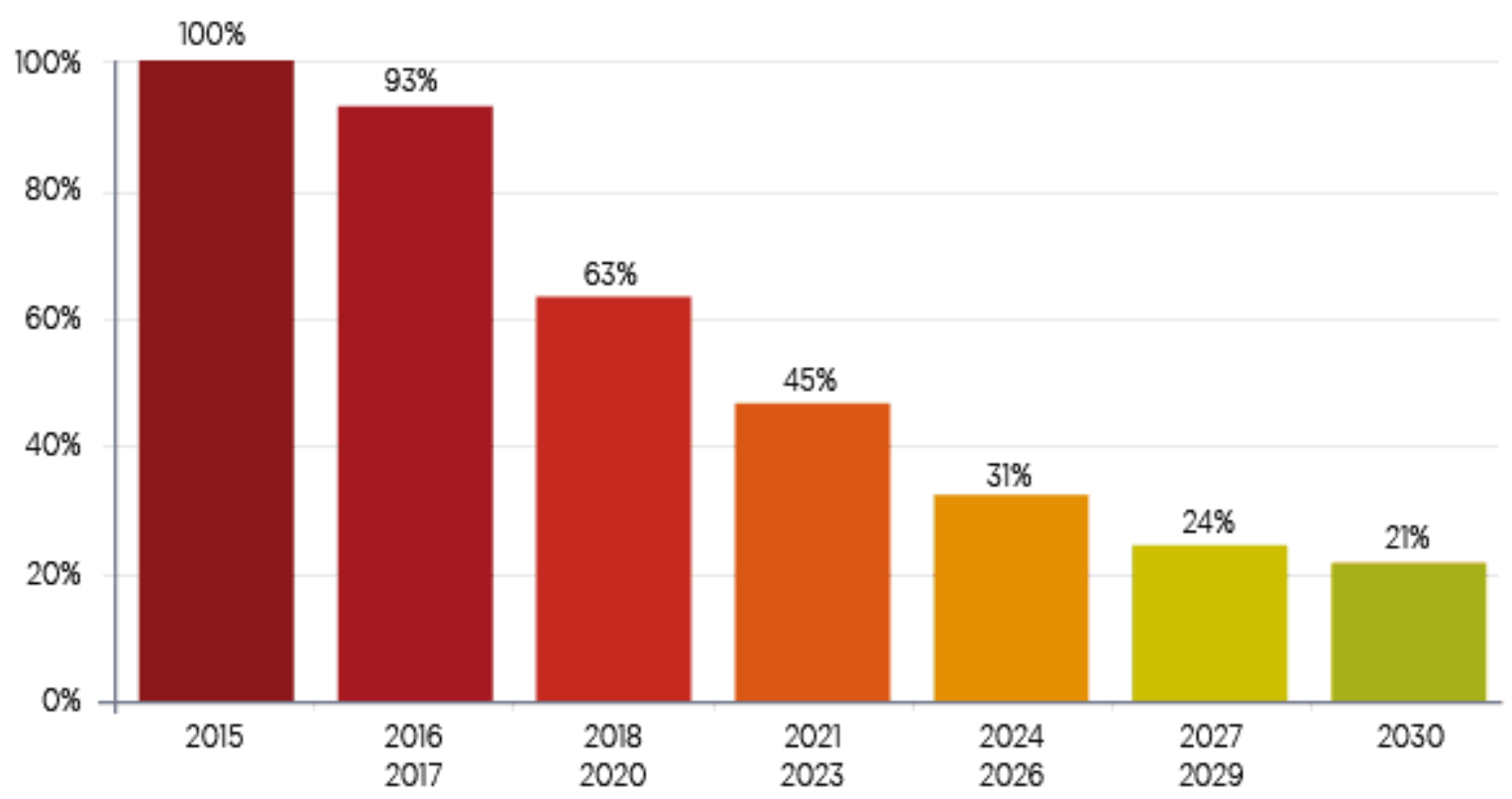

Fig. 4. Hydrofluorocarbon (HFCs) phase-down schedule (Co2e \%) [10]

Refrigerants need to be low-GWP, zero -ODP, high-capacity, low-pressure, and non-toxic, and should, thus, be mixed with HCs and HFOs; however, current refrigerants need to developed. An alternative is to incorporate other HFCs. R32 is low-GWP, zero ODP, high-capacity, and non-toxic, but operates under high pressure and is flammable; in contrast to R134a, which possesses highly similar properties but can operate under low pressure and has low capacity. Current refrigeration systems use R22 [41], as well as R417A [42], R417B [43], R422A [44], R422B [45], R422C [46], R422D [47], R424A [48], R433A [49], R437A [50], R438A [51], and R453A [52], all of which were developed as alternatives to R22 and which are mixed with HCs and HFCs, as shown in Table 1-4. The lowest normal boiling points (of R422A and R422C) are $-46.80^{\circ} \mathrm{C}$ and $-46.20^{\circ} \mathrm{C}$, respectively, lower than that of R22 by $12.82 \%$ and $11.69 \%$. This is due to the presence of hydrofluorocarbon (HFCs) R125 in their composition ( $85.1 \%$ and $82.0 \%$, respectively), consistent with those of R410A and R507, which have boiling points of $-51.6{ }^{\circ} \mathrm{C}$ and $-46.74{ }^{\circ} \mathrm{C}$, respectively, and are considered attractive as alternative refrigerants to R134a and R404A, due to their HFCs R125 content of 50\%. The boiling point of R125 is $-48.1{ }^{\circ} \mathrm{C}$, with a high GWP value $(3,450)$; leading to $\mathrm{R} 422 \mathrm{~A}$ and $\mathrm{R} 422 \mathrm{C}$ having the high GWP values of 3,143 and 3,185, respectively. R422A and R422C also have hydrocarbon (HCs) R601a in their composition (3\%). The boiling point and GWP of R601a are 0 and $-11.73{ }^{\circ} \mathrm{C}$, respectively, the effect of which is reducing the GWP and increasing the boiling point of refrigerant mixtures it is contained in. The lower GWP, compared with R22 $f$ R453A and R437A (1,765 and 1,805, respectively) is due to hydrofluorocarbon (HFCs) R134a (53.8\% and 78.5\%) in their composition and hydrofluorocarbon (HFCs) R32 (20\%) in the composition of R453A; this is consistent with R407A, R407H, and R407F, which combine R134a and R32 with R744 in contents of $6 \%$ and $3 \%$, respectively, in their compositions. The boiling point and GWP naturally change when adjusting the composition of the refrigerant. The refrigerant effect and heat rejection of R453A were found to be higher than those of R22, due to the presence of hydrofluorocarbon (HFCs) R32 (20\%). R453A also has the hydrocarbon (HCs) R600 (0.6\%) in its composition. The lowest refrigerant work was found for R422A, which possesses HCs R600a (3\%) in its composition.

The mixed-refrigerant design should be comparable to natural refrigerants, in terms of having a strong refrigerant effect and high heat rejection, but certain hydrocarbon refrigerant types (e.g., R290 and R1270) are commonly selected for their refrigerant effect and high heat rejection. 
Table 1

Properties of R22, R417A, and R417B

\begin{tabular}{llll}
\hline Condition & \multicolumn{3}{l}{ Medium Temperature } \\
\hline Refrigerant & R22 [41] & R417A [42] & R417B [43] \\
Composition & R22 & R125/R134a/R600 & R125/134a/600 \\
Mass percentage & 100 & $46.6 / 60 / 3.4$ & $79 / 18.3 / 2.7$ \\
Boiling point $\left({ }^{\circ} \mathrm{C}\right)$ & -40.80 & -39.10 & -45.20 \\
Critical Pressure $(\mathrm{kPa})$ & 4,990 & 4,036 & 3,737 \\
Critical Temperature $\left({ }^{\circ} \mathrm{C}\right)$ & 96 & 87 & 74 \\
ODP & 0.055 & 0 & 0 \\
GWP & 1,600 & 1,950 & 3,027 \\
Class & $\mathrm{A} 1$ & $\mathrm{~A} 1$ & $\mathrm{~A} 1$ \\
Lubricant type & $\mathrm{MO}$ & $\mathrm{MO} / \mathrm{AB} / \mathrm{POE}$ & $\mathrm{MO} / \mathrm{POE}$ \\
\hline
\end{tabular}

Table 2

Properties of R422A, R422B, and R422C

\begin{tabular}{llll}
\hline Condition & \multicolumn{3}{l}{ Medium Temperature } \\
\hline Refrigerant & R422A [44] & R422B [45] & R422C [46] \\
Composition & R125/R134a/R600a & R125/R134a/R600a & R125/R134a/R600a \\
Mass percentage & $85.1 / 11.5 / 3.4$ & $55 / 42 / 3$ & $82 / 15 / 3$ \\
Boiling point $\left({ }^{\circ} \mathrm{C}\right)$ & -46.80 & -41.59 & -46.20 \\
Critical Pressure $(\mathrm{kPa})$ & 3,665 & 3,857 & 3,696 \\
Critical Temperature $\left({ }^{\circ} \mathrm{C}\right)$ & 72 & 82 & 72 \\
ODP & 0 & 0 & 0 \\
GWP & 2,530 & 2,526 & 3,085 \\
Class & $\mathrm{A} 1$ & $\mathrm{~A} 1$ & $\mathrm{A0}$ \\
Lubricant type & $\mathrm{MO} / \mathrm{AB} / \mathrm{POE}$ & $\mathrm{MO} / \mathrm{POE}$ & $\mathrm{MO} / \mathrm{POE}$ \\
\hline
\end{tabular}

Table 3

Properties of R422D, R424A, and R437A

\begin{tabular}{llll}
\hline Condition & \multicolumn{2}{l}{ Medium Temperature } & \\
\hline Refrigerant & R422D $[47]$ & R424A [48] & R437A [50] \\
Composition & R125/R134a/R600a & R125/R134a/R600/R600a/R601a & R125/134A/R600/R601 \\
Mass percentage & $62.1 / 31.5 / 3.4$ & $50.5 / 47 / 1 / 0.9 / 0.9$ & $19.5 / 78.5 / 1.4 / 0.6$ \\
Boiling point $\left({ }^{\circ} \mathrm{C}\right)$ & -43.50 & -38.70 & -32.65 \\
Critical Pressure $(\mathrm{kPa})$ & 3,795 & 4,040 & 4,003 \\
Critical Temperature $\left({ }^{\circ} \mathrm{C}\right)$ & 80 & 89 & 95 \\
ODP & 0 & 0 & 0 \\
GWP & 2,330 & 2,440 & 1,805 \\
Class & $\mathrm{A} 1$ & $\mathrm{~A} 1$ & $\mathrm{~A} 1$ \\
Lubricant type & $\mathrm{MO} / \mathrm{AB} / \mathrm{POE}$ & $\mathrm{MO} / \mathrm{AB} / \mathrm{POE}$ & $\mathrm{MO} / \mathrm{POE}$ \\
\hline
\end{tabular}

Table 4

Properties of R438A and R453A

\begin{tabular}{lll}
\hline Condition & Medium Temperature & \\
\hline Refrigerant & R438A [51] & R R453A [52] \\
Composition & R125/134A/R32/R600/R601a & R125/R32/R134A/R227ea/R600/R601a \\
Mass percentage & $45 / 44.2 / 8.5 / 1.7 / 0.6$ & $20 / 20 / 53.8 / 5 / 0.6 / 0.6$ \\
Boiling point $\left({ }^{\circ} \mathrm{C}\right)$ & -42.61 & -42.20 \\
Critical Pressure $(\mathrm{kPa})$ & 4,179 & 4,530 \\
Critical Temperature $\left({ }^{\circ} \mathrm{C}\right)$ & 84 & 88 \\
ODP & 0 & 0 \\
GWP & 2,265 & 1,765 \\
Class & $\mathrm{AO}$ & $\mathrm{A} 1$ \\
Lubricant type & $\mathrm{MO} / \mathrm{POE}$ & $\mathrm{MO} / \mathrm{POE}$ \\
\hline
\end{tabular}


However, the high refrigerant work and high operating pressure of such refrigerants affect the power consumption of the compressor. Considering systems that operate with R134a [53], R450A [54], R456A [40], R513A [55], and R515A [40] are all refrigerants that have been developed as an alternative to R134a, which are mixed with HCs, HFCs, and HFOs and operated under low pressure, achieving similar results to R453A operating under high pressure with $20 \%$ hydrofluorocarbon (HFCs) R32 content in its composition, as shown in Table 5.

Table 5

Properties of R134a, R450A, R456A, R513A, and R515A

\begin{tabular}{llllll}
\hline Refrigerant & R134a [53] & R450A [54] & R456A [40] & R513A [55] & R515A [40] \\
\hline Composition & R134a & R134a/ & R134a/R32/ & R134a/ & R227ea/ \\
& & R12354ze(E) & R1234ze (E) & R1234yf & R1234ze(E) \\
Mass percentage & 100 & $42 / 58$ & $45 / 6 / 49$ & $44 / 56$ & $12 / 88$ \\
Boiling point $\left({ }^{\circ} \mathrm{C}\right)$ & -26.07 & -23.5 & -30.75 & -28.3 & -18.75 \\
Critical pressure $(\mathrm{kPa})$ & 4060 & 3814 & 4175 & 3700 & 3555 \\
Critical temperature $\left({ }^{\circ} \mathrm{C}\right)$ & 101.06 & 105.87 & 102.65 & 97.7 & 108.65 \\
ODP & 0 & 0 & 0 & 0 & 0 \\
GWP & 1430 & 547 & 687 & 570 & 387 \\
Class & $\mathrm{A} 1$ & $\mathrm{~A} 1$ & $\mathrm{~A} 1$ & $\mathrm{~A} 1$ & $\mathrm{~A} 1$ \\
Lubricant type & $\mathrm{POE}$ & $\mathrm{POE}$ & $\mathrm{POE}$ & $\mathrm{POE}$ & $\mathrm{POE}$ \\
\hline
\end{tabular}

The fourth-generation refrigerant R404A was the basis for this research, which is currently the most-used refrigerant, as shown in Figure 5. R404A is an azeotropic blend of 143a/125/134a with zero ODP, which is non-flammable, non-toxic, and operates under low pressure, with a GWP of 3922 [56]. R407A [57], R407F [58], R407H [59], R410A [60], R442A [52], R448A [61], R449A [62], R452A [63], R453A [64], and R463A [65] are all refrigerants developed to be retrofitted to replace $R 404 A$, as shown in Table 6-9.

\section{Meat}

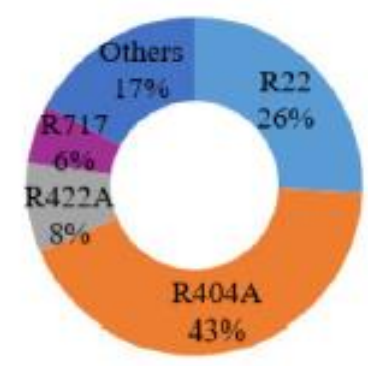

Fish

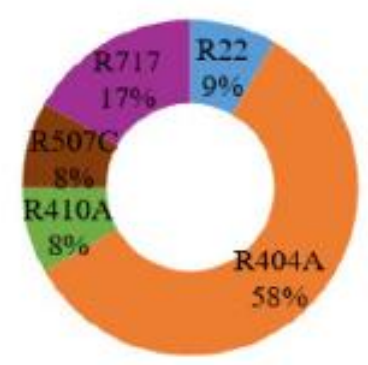

Milk \& Dairy

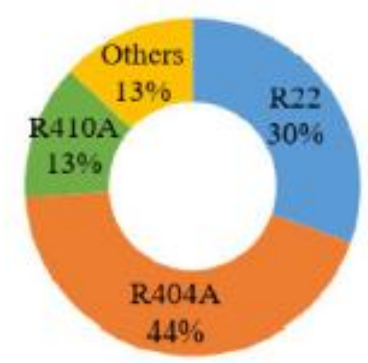

Wines

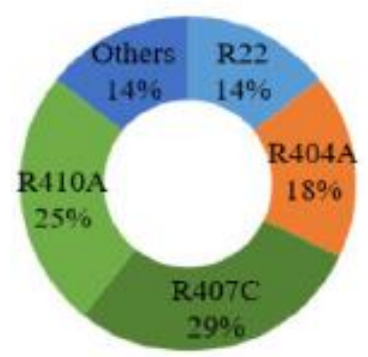

\section{Fruit \& Vegetables}

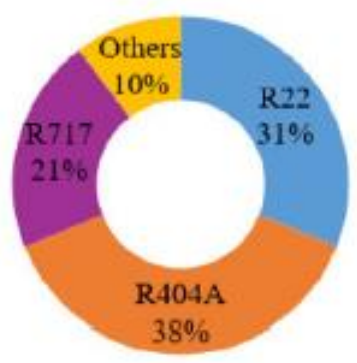

Food Distribution

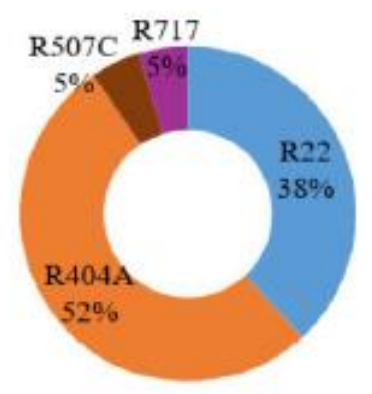

Fig. 5. Top refrigerants in food industry [9] 
The lowest normal boiling point of R463A is $-60.13^{\circ} \mathrm{C}$, which is lower than that of R404A by $23 \%$. This is due to hydrofluorocarbon (HFCs) R32 (36\%) and carbon dioxide $\left(\mathrm{CO}_{2}\right)$ R744 (7\%) being in its composition, consistent with R445A [64] and R455A [65]. R445A and R455A both have low boiling points $\left(-49.15{ }^{\circ} \mathrm{C}\right.$ and $-52.0^{\circ} \mathrm{C}$, respectively) and are attractive as alternative refrigerants with lower GWP than R134a and R404A, due to the $\mathrm{CO}_{2} \mathrm{R} 744$ content of $6 \%$ and $3 \%$, respectively, in their compositions. R448A and R449A displayed the lowest GWP values of 1273 and 1282, respectively, due to the HFOs R1234yf and R1234ze(E) in their compositions. The GWP of R463A has been found to be 1377 , with a lower boiling point than that of R404A by $23 \%$; even though the ratio of R1234yf in R463A is less than that in both R448A and R449A. However, the GWP of R463A has been found to be slightly higher than those of R448A and R449A. The cost of R463A is also lower than R448A and R449A.

Table 6

Properties of R404A, R407A, and R407F

\begin{tabular}{llll}
\hline Condition & \multicolumn{3}{l}{ Medium Temperature } \\
\hline Refrigerant & R404A [56] & R404A [56] & R404A [56] \\
Composition & R125/R143/R134a & R125/R143/R134a & R125/R143/R134a \\
Mass percentage & $44 / 52 / 4$ & $44 / 52 / 4$ & $44 / 52 / 4$ \\
Boiling point $\left({ }^{\circ} \mathrm{C}\right)$ at 1 kPa & -46.6 & -46.6 & -46.6 \\
Critical pressure $(\mathrm{kPa})$ & 3728 & 3728 & 3728 \\
Critical temperature $\left({ }^{\circ} \mathrm{C}\right)$ & 72.1 & 72.1 & 72.1 \\
ODP & 0 & 0 & 0 \\
GWP & 3943 & 3943 & 3943 \\
Class & $\mathrm{A} 1$ & $\mathrm{~A} 1$ & $\mathrm{~A} 1$ \\
Lubricant type & $\mathrm{POE}$ & $\mathrm{POE}$ & $\mathrm{POE}$ \\
Qevap $(\mathrm{kJ} / \mathrm{kg})$ & 139.02 & 139.02 & 139.02 \\
Qcond $(\mathrm{kJ} / \mathrm{kg})$ & 198.57 & 198.57 & 198.57 \\
Work $(\mathrm{kJ} / \mathrm{kg})$ & 59.55 & 59.55 & 59.55 \\
COPc & 2.335 & 2.335 & 2.335 \\
Evaporator pressure $(\mathrm{kPa})$ & 477.3 & 477.3 & 477.3 \\
Condenser pressure $(\mathrm{kPa})$ & 2284.10 & 2284.10 & 2284.10 \\
\hline
\end{tabular}

Table 7

Properties of R407H, R410A, and R422A

\begin{tabular}{llll}
\hline Condition & \multicolumn{4}{l}{ Medium Temperature } \\
\hline Refrigerant & R407H [59] & R410A [60] & R442A [52] \\
Composition & R125/R32/R134a & R125/R32 & $\begin{array}{l}\text { R125/R32/R134a } \\
\text { /R227ea/R152A }\end{array}$ \\
& & & $31 / 31 / 30 / 5 / 3$ \\
Mass percentage & $15 / 32.5 / 52.5$ & $50 / 50$ & -46.5 \\
Boiling point $\left({ }^{\circ} \mathrm{C}\right)$ & -44.6 & -51.6 & 4760 \\
Critical pressure $(\mathrm{kPa})$ & 4856 & 4811 & 82.4 \\
Critical temperature $\left({ }^{\circ} \mathrm{C}\right)$ & 86.53 & 70.81 & 0 \\
ODP & 0 & 0 & 1888 \\
GWP & 1400 & 1900 & $\mathrm{~A} 1$ \\
Class & $\mathrm{A} 1$ & $\mathrm{~A} 1$ & $\mathrm{POE}$ \\
Lubricant type & $\mathrm{POE}$ & $\mathrm{POE}$ & 184.39 \\
Qevap $(\mathrm{kJ} / \mathrm{kg})$ & 155.8 & 188.53 & 266.68 \\
Qcond $(\mathrm{kJ} / \mathrm{kg})$ & 229.56 & 271.65 & 82.29 \\
Work $(\mathrm{kJ} / \mathrm{kg})$ & 73.76 & 83.12 & 2.241 \\
COPc & 2.112 & 2.268 & 417.50 \\
Evaporator pressure $(\mathrm{kPa})$ & 379.10 & 636.30 & 410.50 \\
Condenser pressure $(\mathrm{kPa})$ & 2265.80 & 3013.70 & 2342.40 \\
\hline
\end{tabular}


Hydrofluorocarbons can also be combined with carbon dioxide $\left(\mathrm{CO}_{2}\right)$, which has a lower GWP and boiling point. The lower boiling point and GWP are consistent with the evolution of the fourthgeneration refrigerants that contain a mixture of HFCs, HFOs, HCs, and natural refrigerants, which are required to produce a low-GWP, zero ODP, high-capacity, low-operating pressure, and non-toxic refrigerant. The refrigerant effect and heat rejection of R463A have been found to be higher than those of R404A, due to the presence of hydrofluorocarbon (HFCs) R32 (36\%) and carbon dioxide $\left(\mathrm{CO}_{2}\right)$ R744 (7\%) in its composition, consistent with R424A and R453A, which are composed of hydrocarbons (HCs) at contents of $1.8 \%$ and $1.2 \%$, respectively. The mixed-refrigerant design should be comparable to natural refrigerants, in terms of having a strong refrigerant effect and high heat rejection. Refrigerants operated under low pressure display low refrigerant work value; in this case, the lowest refrigerant work is observed in R452A. This refrigerant possesses HFOs R1234yf and R1234ze(E) in its composition. The highest refrigerant work value is observed for R463A, which contains hydrofluorocarbon (HFCs) R32 (36\%) and carbon dioxide $\left(\mathrm{CO}_{2}\right)$ R744 (7\%), and operates at the highest evaporator pressure. This means that a refrigerant system which is operated at low pressure should use a mix of refrigerants that can operate under low pressure, such as R1234yf, R1234ze(E), and R134a. R450A [49], R456A [50], R513A [51], and R515A [50], which are mixed with hydrofluoroolefins (HFOs) and can operate under low pressure, have achieved similar results. R453A had the highest COPc, as R453A does not have the highest refrigerant effect and heat rejection, nor the lowest boiling point, but can be operated under low pressure, which has an impact on low refrigerant work. The COPc level of R463A was recorded at 1.34 , which is $10 \%$ higher than that of R404A under low-temperature conditions only.

Table 8

Properties of R448A, R449A, and R452A

\begin{tabular}{llll}
\hline Condition & Medium Temperature & & \\
\hline Refrigerant & R448A [61] & R449A [62] & R452A [63] \\
Composition & R125/R32/R134a/ & R125/R32/R134a/R1234yf & R125/R32/R1234yf \\
& R1234yf/R12354ze(E) & & \\
Mass percentage & $26 / 26 / 20 / 21 / 7$ & $24.7 / 24.3 / 25.7 / 25.3$ & $59 / 11 / 30$ \\
Boiling point $\left({ }^{\circ} \mathrm{C}\right)$ & -40.1 & -45.95 & -47.2 \\
Critical pressure $(\mathrm{kPa})$ & 4675 & 4662 & 4014 \\
Critical temperature $\left({ }^{\circ} \mathrm{C}\right)$ & 83.66 & 83.85 & 75.05 \\
ODP & 0 & 0 & 0 \\
GWP & 1273 & 1282 & 1945 \\
Class & $\mathrm{A} 1$ & $\mathrm{~A} 1$ & $\mathrm{~A} 1$ \\
Lubricant type & $\mathrm{POE}$ & $\mathrm{POE}$ & $\mathrm{POE}$ \\
Qevap (kJ/kg) & 172.76 & 170.94 & 92.46 \\
Qcond $(\mathrm{kJ} / \mathrm{kg})$ & 249.11 & 245.91 & 141.82 \\
Work $(\mathrm{kJ} / \mathrm{kg})$ & 76.35 & 74.98 & 49.36 \\
COPc & 2.263 & 2.28 & 1.873 \\
Evaporator pressure $(\mathrm{kPa})$ & 410.60 & 409.60 & 443.70 \\
Condenser pressure (kPa) & 2265.90 & 2240.20 & 2423.00 \\
\hline
\end{tabular}


Table 9

Properties of R453A and R463A

\begin{tabular}{lll}
\hline Condition & Medium Temperature & \\
\hline Refrigerant & R453A [64], & R463A [65] \\
& R125/R32/R134a/R227ea/ & \\
Composition & R600/R601a & R125/R32/R134a/R1234yf/R744 \\
Mass percentage & $20 / 20 / 53.8 / 5 / 0.6 / 0.6$ & $30 / 36 / 14 / 14 / 6$ \\
Boiling point $\left({ }^{\circ} \mathrm{C}\right)$ & -42.2 & -60.13 \\
Critical pressure $(\mathrm{kPa})$ & 4530 & 5283 \\
Critical temperature $\left({ }^{\circ} \mathrm{C}\right)$ & 87.9 & 73.15 \\
ODP & 0 & 0 \\
GWP & 1765 & 1377 \\
Class & $\mathrm{A} 1$ & $\mathrm{~A} 1$ \\
Lubricant type & $\mathrm{POE}$ & $\mathrm{POE}$ \\
Qevap $(\mathrm{kJ} / \mathrm{kg})$ & 184.91 & 178.36 \\
Qcond $(\mathrm{kJ} / \mathrm{kg})$ & 312 & 255.92 \\
Work $(\mathrm{kJ} / \mathrm{kg})$ & 127.56 & 77.56 \\
COPc & 1.45 & 2.3 \\
Evaporator pressure $(\mathrm{kPa})$ & 121.00 & 342.10 \\
Condenser pressure $(\mathrm{kPa})$ & 1808.70 & 2002.50 \\
\hline
\end{tabular}

The promising results for COPc obtained by R407F, R448A, and R449A are due to the refrigerants being operated under low pressure, which has an impact on low refrigerant work. The same effect has been observed for R453A; however, these four refrigerants do not have a low normal boiling point or high $\mathrm{Cp}$ liquid/vapor or liquid/vapor conductivity. This shows that a mixed-refrigerant design should consider all parameters, such as the GWP, boiling point, $\mathrm{Cp}$ liquid/vapor and liquid/vapor conductivity, refrigerant effect, heat rejection, refrigerant work, evaporator pressure, high pressure, and COPc.

Due to the costs shown in Figure 6 [43], refrigerants should be mixed with HFOs. The figure shows that the HFOs had the highest refrigerant cost, but does not include HCs refrigerant costs compared with HFO refrigerant costs, and is presented for comparative purposes in this research (as it is generally composed of $\mathrm{HCs}$ ). The class properties of hydrocarbon refrigerants are shown in Figure 7 below. Some zero ODP and near-zero GWP Class A3 refrigerants, as shown in Table 10 and 11, are R170 [66], R290 [67], R600 [68], R600a [69] and Table 2 for R601 [70], R601a [71], R1150 [72], and $\mathrm{R} 1270$ [73]. The lowest boiling points were found to be $-88.70^{\circ} \mathrm{C}$ and $-103.8^{\circ} \mathrm{C}$, respectively, for R170 and R1270; however, their critical temperatures were found to be $32.17{ }^{\circ} \mathrm{C}$ and $9.5^{\circ} \mathrm{C}$. This means that these cannot be operated as refrigerants in accordance with the CAN/ANSI/AHRI540 AirConditioning, Heating, and Refrigeration Institute (AHRI) standards considered in this research [7476]. R290 and R1270 were found to have boiling points near that of with R22 $\left(-42.1^{\circ} \mathrm{C}\right.$ and $-47.7^{\circ} \mathrm{C}$, respectively), but operate at high condenser pressures, which affect the evaporator pressure, condenser pressure, and cooling coefficient of performance. Therefore, in this research, we used R1270 for the base line for new refrigerant mixes, as R1270 has a low boiling point and high refrigerant effect. 


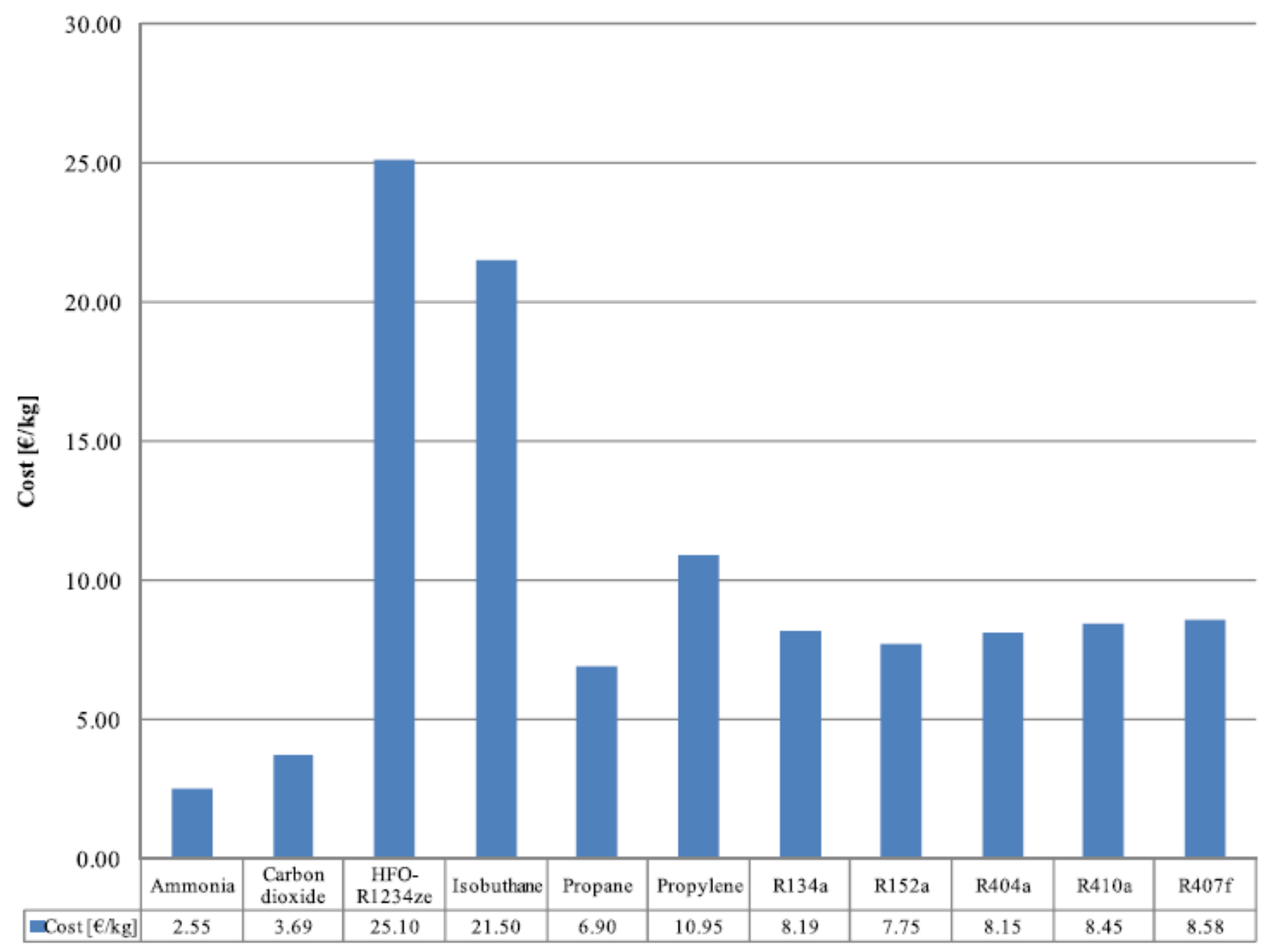

Fig. 6. Cost of refrigerant [43]

Table 10

Properties of R170, R290, R600, and R600a

\begin{tabular}{lllll}
\hline Condition & \multicolumn{4}{l}{ Medium Temperature } \\
\hline Refrigerant & $\mathrm{R} 170[66]$ & $\mathrm{R} 290[67]$ & $\mathrm{R} 600[68]$ & $\mathrm{R600a}[69]$ \\
Formula & $\mathrm{C}_{2} \mathrm{H}_{6}$ & $\mathrm{C}_{3} \mathrm{H}_{8}$ & $\mathrm{C}_{4} \mathrm{H}_{10}$ & $\mathrm{C}_{4} \mathrm{H}_{10}$ \\
Chemical name & Ethane & Propane & Butane & Isobutane \\
Boiling point $\left({ }^{\circ} \mathrm{C}\right)$ & -88.7 & -42.1 & -0.5 & -11.73 \\
Critical Pressure $(\mathrm{kPa})$ & 4872 & 4251 & 3796 & 3629 \\
Critical Temperature $\left({ }^{\circ} \mathrm{C}\right)$ & 32.17 & 96.74 & 151.98 & 134.66 \\
ODP & 0 & 0 & 0 & 0 \\
GWP & 3 & 3 & 3 & 3 \\
Class & $\mathrm{A} 3$ & $\mathrm{~A} 3$ & $\mathrm{~A} 3$ & $\mathrm{~A} 3$ \\
Lubricant type & $\mathrm{MO} / \mathrm{POE}$ & $\mathrm{MO} / \mathrm{POE}$ & $\mathrm{MO} / \mathrm{POE}$ & $\mathrm{MO} / \mathrm{POE}$ \\
Qevap $(\mathrm{kJ} / \mathrm{kg})$ & $\mathrm{N} / \mathrm{A}$ & 240.37 & 261.99 & 231.52 \\
Qcond $(\mathrm{kJ} / \mathrm{kg})$ & $\mathrm{N} / \mathrm{A}$ & 349.48 & 371.49 & 332.01 \\
Work $(\mathrm{kJ} / \mathrm{kg})$ & $\mathrm{N} / \mathrm{A}$ & 109.11 & 109.51 & 100.49 \\
COPc & $\mathrm{N} / \mathrm{A}$ & 2.2 & 2.39 & 2.3 \\
Evaporator Pressure $(\mathrm{kPa})$ & $\mathrm{N} / \mathrm{A}$ & 385.9 & 80.2 & 123.5 \\
Condenser Pressure $(\mathrm{kPa})$ & $\mathrm{N} / \mathrm{A}$ & 1803.1 & 535.4 & 736.8 \\
\hline & & & &
\end{tabular}


Table 11

Properties of R601, R601a, R1150, and R1270

\begin{tabular}{lllll}
\hline Condition & \multicolumn{4}{l}{ Medium Temperature } \\
\hline Refrigerant & $\mathrm{R} 601[70]$ & $\mathrm{R} 601 \mathrm{a}[71]$ & $\mathrm{R} 1150[72]$ & $\mathrm{R} 1270[73]$ \\
Formula & $\mathrm{C}_{5} \mathrm{H}_{12}$ & $\mathrm{C}_{5} \mathrm{H}_{12}$ & $\mathrm{C}_{2} \mathrm{H}_{4}$ & $\mathrm{C}_{3} \mathrm{H}_{6}$ \\
Chemical name & Pentane & Isopentane & Ethylene & Propylene \\
Boiling point $\left({ }^{\circ} \mathrm{C}\right)$ & 36.1 & 27.7 & -103.8 & -47.7 \\
Critical Pressure $(\mathrm{kPa})$ & 3370 & 3378 & 5042 & 4660 \\
Critical Temperature $\left({ }^{\circ} \mathrm{C}\right)$ & 196.55 & 187.2 & 9.5 & 92.4 \\
ODP & 0 & 0 & 0 & 0 \\
GWP & 4 & 4 & 3 & 2 \\
Class & $\mathrm{A3}$ & $\mathrm{A} 3$ & $\mathrm{A3}$ & $\mathrm{A} 3$ \\
Lubricant type & $\mathrm{MO} / \mathrm{POE}$ & $\mathrm{MO} / \mathrm{POE}$ & $\mathrm{MO} / \mathrm{POE}$ & $\mathrm{MO} / \mathrm{POE}$ \\
Qevap $(\mathrm{kJ} / \mathrm{kg})$ & 267.22 & 248.05 & $\mathrm{~N} / \mathrm{A}$ & 247.13 \\
Qcond $(\mathrm{kJ} / \mathrm{kg})$ & 376.31 & 350.99 & $\mathrm{~N} / \mathrm{A}$ & 358.77 \\
Work $(\mathrm{kJ} / \mathrm{kg})$ & 109.09 & 102.94 & $\mathrm{~N} / \mathrm{A}$ & 111.64 \\
COPc & 2.45 & 2.41 & $\mathrm{~N} / \mathrm{A}$ & 2.21 \\
Evaporator Pressure $(\mathrm{kPa})$ & 18.1 & 25.9 & $\mathrm{~N} / \mathrm{A}$ & 478.1 \\
Condenser Pressure $(\mathrm{kPa})$ & 175.1 & 225.4 & $\mathrm{~N} / \mathrm{A}$ & 2143.8 \\
\hline
\end{tabular}

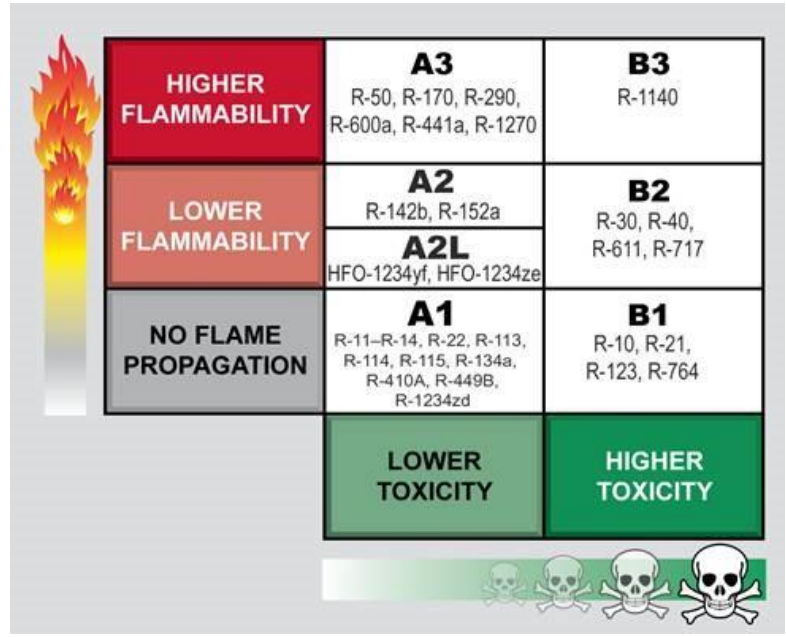

Fig. 7. Refrigerant classification [2]

\section{Methodology}

For the properties of refrigerants and the refrigeration simulation system, we used the REFPROP database and CYCLE_D-HX software from the National Institute of Standards and Technology [77-79], respectively, as shown in Figure 8 below. The properties of all refrigerants, summarized in Table 14, conformed to the use of REFPROP and the CYCLE_D-HX software, as stipulated by the National Institute of Standards and Technology (NIST) [77-79], in accordance with the CAN/ANSI/AHRI540 AirConditioning, Heating, and Refrigeration Institute (AHRI) standards, as shown in Table 12 [74-76]. Both software programs can pre-define mixtures and create new refrigerant mixtures. REFPROP can display results related to refrigerant properties under various conditions, and the CYCLE_D-HX software can also display results related to refrigerant cycles under various conditions. The results illustrated the relationships of all parameters, such as GWP, boiling point, refrigerant effect, heat rejection, refrigerant work, evaporator pressure, high pressure, and cooling coefficient of performance (COPc), as well as the result of the decision tree function through datamining using the RapidMiner software (which came first in the 2013 KDnuggets annual software poll [80-82]), as 
shown in Figure 9 below. The baseline refrigerant, using R134a, R32, R125, and R1270, was determined from the literature review [83-89].

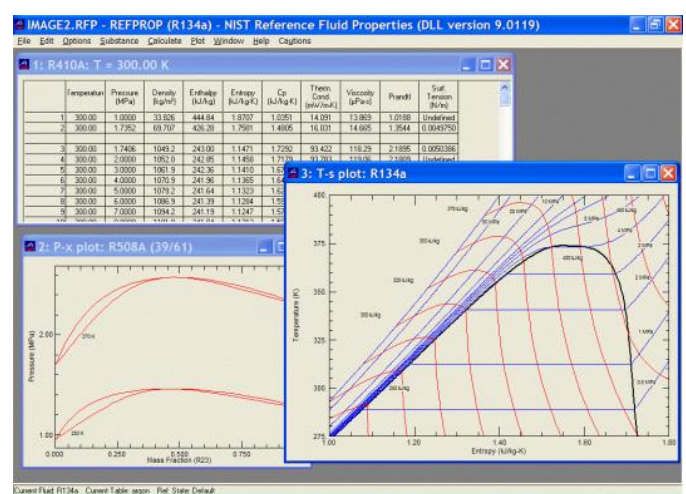

Fig. 8. The REFPROP software used for refrigerant properties [77-79]

Table 12

Standard testing for refrigeration systems [74-76]

\begin{tabular}{llllll}
\hline Temperature Point & \multicolumn{4}{l}{ Air Conditioning and Heat Pump } & \multicolumn{3}{l}{ Refrigeration } \\
\cline { 2 - 6 } & Heating & Cooling & Low & Medium & High \\
\hline Suction dew point $\left({ }^{\circ} \mathrm{C}\right)$ & -15.0 & 10.0 & -31.5 & -6.5 & 7.0 \\
Discharge dew point $\left({ }^{\circ} \mathrm{C}\right)$ & 35.0 & 46.0 & 40.5 & 43.5 & 54.5 \\
Suction return gas temperature $\left({ }^{\circ} \mathrm{C}\right)$ & -4.0 & 21.0 & 4.5 & 18.5 & 18.5 \\
Superheat $(\mathrm{K})$ & 11.0 & 11.0 & 11.0 & 11.0 & 11.0 \\
Subcooling $(\mathrm{K})$ & 0.0 & 0.0 & 0.0 & 0.0 & 0.0 \\
\hline
\end{tabular}

Data Mining Tools used in 2013

(1880 voters)

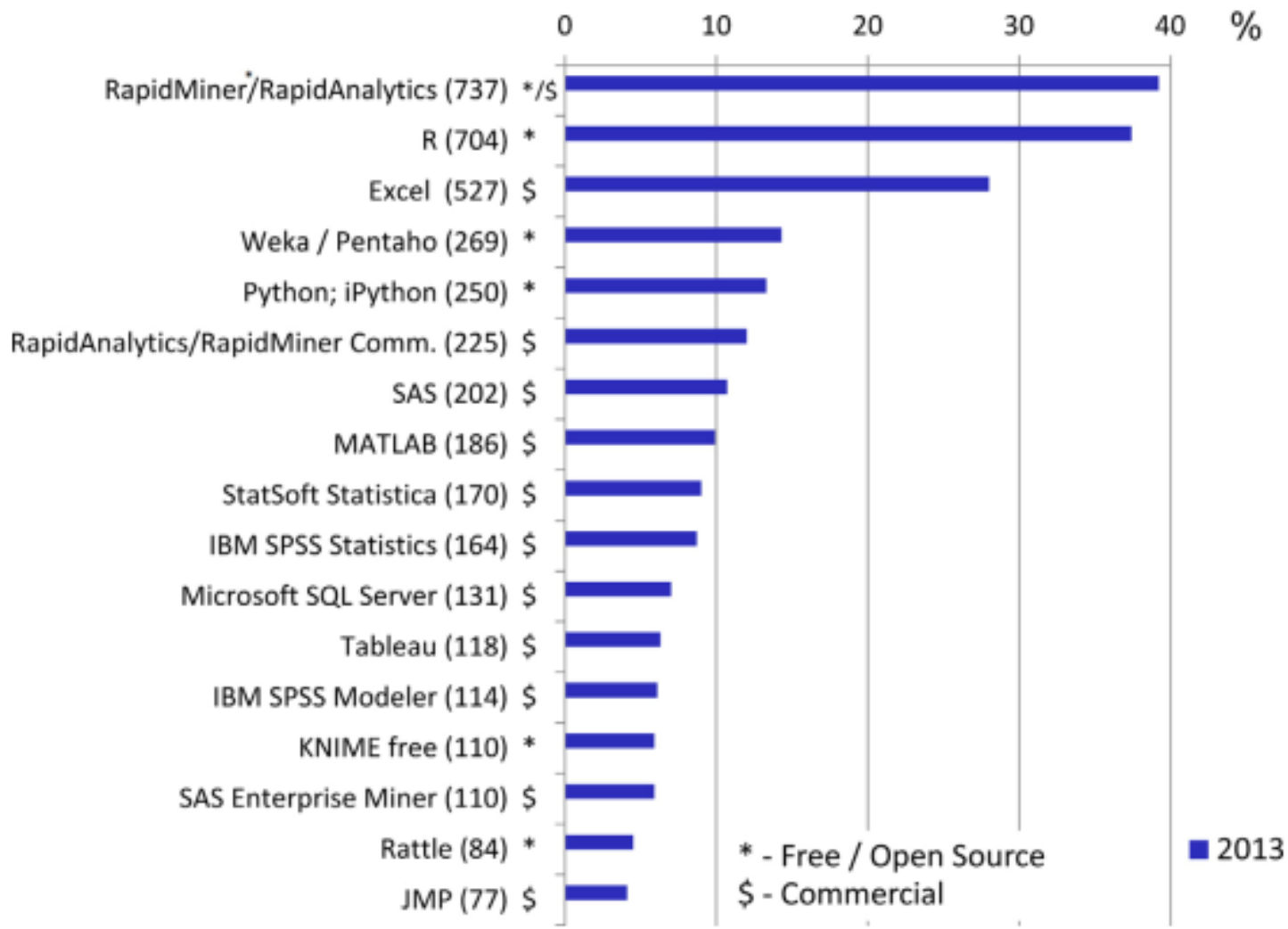

Fig. 9. Report of the KDnuggets annual software poll on the most-used data mining tools [80] 


\section{Results and Discussion}

The refrigerants mixed by R134a, R32, R125 and R1270 that can happen 4,539 type in Table 13 as below has showed the refrigerants mixed by R134a, R32, R125 and R1270 by fixed R1270 in 1\% for refrigerant no frame propagation class $A 1$ and varies mass percentage of R134a, R32 and R125 and the refrigerants mixed class A2 that mass percentage of R32 higher than R125 The GWP calculated by mass percentage of refrigerants and boiling point simulate by REFPROP software at $0.1 \mathrm{Mpa}$ and pressure at evaporator temperature $-6.5^{\circ} \mathrm{C}$ and pressure at condenser temperature $43.5^{\circ} \mathrm{C}$ simulate by and CYCLE_D-HX software from national institute of standards and technology [19] The refrigerant mixed were developed to low GWP, zero ODP, high capacity, low pressure, no toxify [6] that can select the refrigerant requirement from refrigerant data 4,539 type by rapid minor software that first of report of the software poll that used for data mining tool. The refrigerant requirement was class A1, boiling point lower than boiling point R404 at $-46.5^{\circ} \mathrm{C}$ and GWP lower than 2000 . The datamining functional by decision tree in rapid minor software showed the 4 refrigerant result that follow refrigerant requirement as Figure 10, 11 and Table 14 below.

Table 13

Refrigerant mixtures of R134a, R32, R125, and R1270

\begin{tabular}{|c|c|c|c|c|c|c|c|c|}
\hline Refrigerant & R134a & R32 & R125 & R1270 & Summary & GWP & Boiling Point & Class A \\
\hline R-No.1 & 1 & 1 & 97 & 1 & 100 & 3,366 & -47.91 & 1 \\
\hline R-No.2 & 1 & 2 & 96 & 1 & 100 & 3,339 & -47.95 & 1 \\
\hline R-No.3 & 1 & 3 & 95 & 1 & 100 & 3,311 & -47.98 & 1 \\
\hline R-No.4 & 1 & 4 & 94 & 1 & 100 & 3,283 & -48.02 & 1 \\
\hline$\bullet$ & $\bullet$ & $\bullet$ & $\bullet$ & $\bullet$ & $\bullet$ & $\bullet$ & $\bullet$ & $\bullet$ \\
\hline R-No.94 & 1 & 94 & 4 & 1 & 100 & 786 & -51.26 & 2 \\
\hline R-No.95 & 1 & 95 & 3 & 1 & 100 & 758 & -51.30 & 2 \\
\hline R-No.96 & 1 & 96 & 2 & 1 & 100 & 730 & -51.33 & 2 \\
\hline R-No.97 & 2 & 3 & 94 & 1 & 100 & 3,289 & -47.76 & 1 \\
\hline R-No.98 & 2 & 4 & 93 & 1 & 100 & 3,262 & -47.80 & 1 \\
\hline R-No.99 & 2 & 5 & 92 & 1 & 100 & 3,234 & -47.84 & 1 \\
\hline R-No.100 & 2 & 6 & 91 & 1 & 100 & 3,206 & -47.87 & 1 \\
\hline - & $\bullet$ & $\bullet$ & $\bullet$ & $\bullet$ & $\bullet$ & $\bullet$ & $\bullet$ & $\bullet$ \\
\hline R-No.187 & 2 & 93 & 4 & 1 & 100 & 792 & -51.00 & 2 \\
\hline R-No.188 & 2 & 94 & 3 & 1 & 100 & 764 & -51.04 & 2 \\
\hline R-No.189 & 2 & 95 & 2 & 1 & 100 & 736 & -51.08 & 2 \\
\hline R-No.190 & 3 & 3 & 93 & 1 & 100 & 3,268 & -47.54 & 1 \\
\hline R-No.191 & 3 & 4 & 92 & 1 & 100 & 3,240 & -47.58 & 1 \\
\hline R-No.192 & 3 & 5 & 91 & 1 & 100 & 3,212 & -47.62 & 1 \\
\hline$\bullet$ & $\bullet$ & $\bullet$ & $\bullet$ & $\bullet$ & $\bullet$ & $\bullet$ & $\bullet$ & $\bullet$ \\
\hline R-No.4534 & 92 & 3 & 4 & 1 & 100 & 1,354 & -27.96 & 1 \\
\hline R-No.4535 & 92 & 4 & 3 & 1 & 100 & 1,327 & -28.00 & 2 \\
\hline R-No.4536 & 92 & 5 & 2 & 1 & 100 & 1,299 & -28.04 & 2 \\
\hline R-No.4537 & 93 & 3 & 3 & 1 & 100 & 1,333 & -27.74 & 1 \\
\hline R-No.4538 & 94 & 3 & 2 & 1 & 100 & 1,311 & -27.52 & 2 \\
\hline R-No.4539 & 95 & 3 & 1 & 1 & 100 & 1,290 & -27.30 & 2 \\
\hline
\end{tabular}




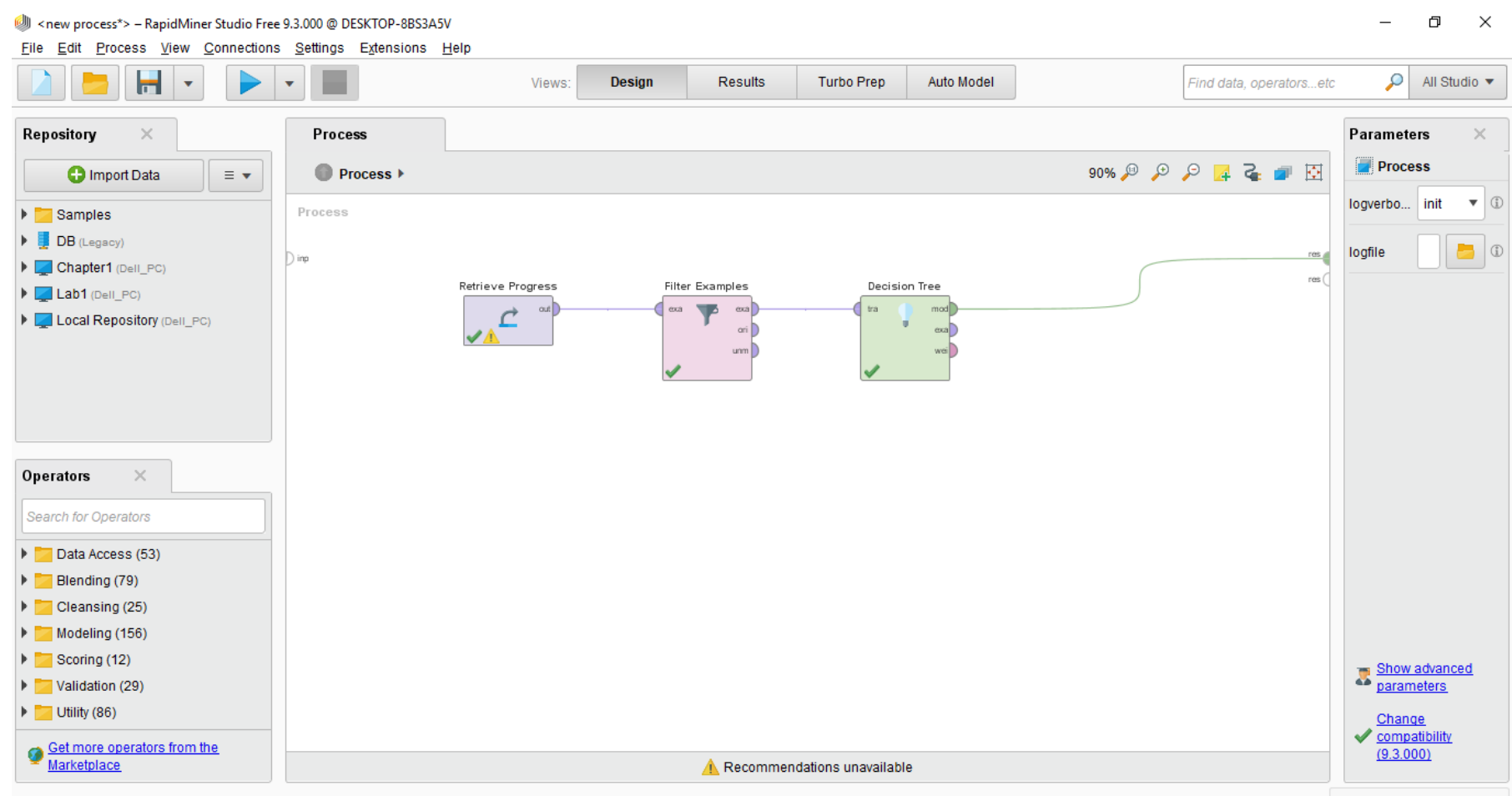

Fig. 10. The datamining function by decision tree in RapidMiner

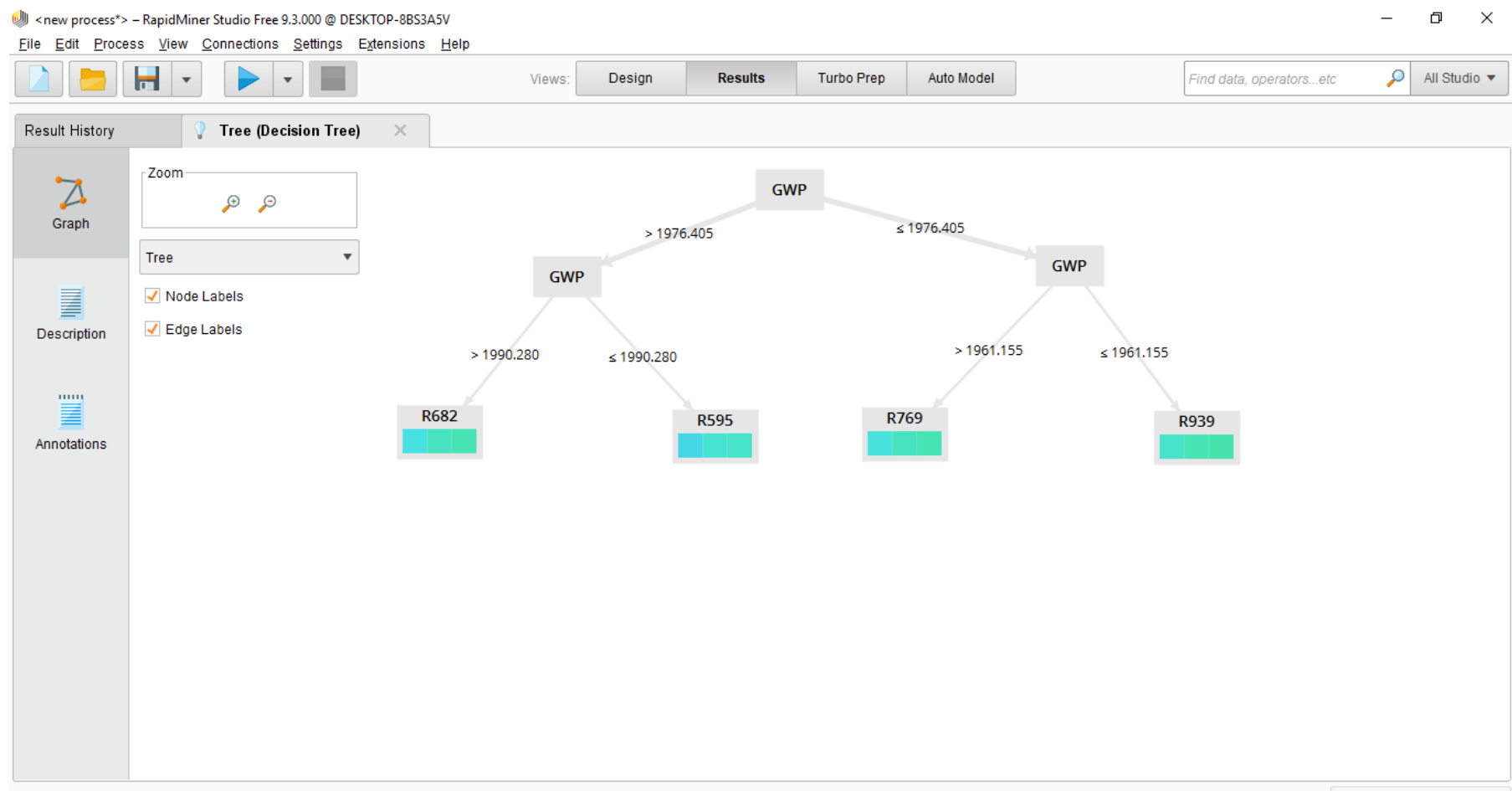

Fig. 11. The four refrigerants following our refrigerant requirements

Table 14

The four refrigerants found using the RapidMiner software

\begin{tabular}{lllllllll}
\hline Refrigerant & R134a & R32 & R125 & R1270 & Summary & GWP & Boiling Point & Class A \\
\hline R-No.682 & 8 & 45 & 46 & 1 & 100 & 1,995 & -47.96 & 1 \\
R-No.595 & 7 & 46 & 46 & 1 & 100 & 1,989 & -48.21 & 1 \\
R-No.769 & 9 & 45 & 45 & 1 & 100 & 1,973 & -47.74 & 1 \\
R-No.939 & 11 & 44 & 44 & 1 & 100 & 1,958 & -47.26 & 1 \\
\hline
\end{tabular}


The simulation system then used the REFPROP and CYCLE_D-HX software of the National Institute of Standards and Technology [19] to define new mixtures from the results of the RapidMiner software, in order to verify that the properties and simulation system follow the CAN/ANSI/AHRI540 standard of the Air-conditioning, Heating, and Refrigeration Institute (AHRI), as shown in Table 14 and 15. All refrigerant results were composed of polyol ester oil (POE), which is classified as a Class A1 incombustible and non-toxic refrigerant. R-No.595 had the lowest boiling point at $-48.21^{\circ} \mathrm{C}$; lower than that of R404A by $4.58 \%$. This was due to the presence of hydrofluorocarbon (HFCs) R32 (36\%) and hydrocarbon (HCS) R1270 (1\%). The lowest GWP was 1,958, 50.34\% lower than that of R404A, which was due to the presence of hydrofluorocarbon (HFCs) R134a (11\%) and hydrocarbon (HCs) R1270 (1\%). The critical pressures and temperatures of all refrigerants were found to be higher than those of R404A and, so, they can all be used in high ambient temperature environments. The highest refrigerant effect was attained by R-No.595, with $142.93 \mathrm{~kJ} / \mathrm{kg}$. The highest heat rejection was $212.52 \mathrm{~kJ} / \mathrm{kg}$, consistent with the normal boiling point. This was due to the presence of hydrofluorocarbon (HFCs) R32 and hydrocarbon (HCs) R1270; however, R32 operates at high pressures, thus affecting the evaporator pressure, condenser pressure, and COPc under medium temperature conditions (as the work of compressor will be high). This shows that a mixed-refrigerant design should consider all parameters, such as the GWP, boiling point, Cp liquid/vapor and liquid/vapor conductivity, refrigerant effect, heat rejection, refrigerant work, evaporator pressure, high pressure, and COPc.

\section{Table 15}

Results of the simulation system using REFPROP and CYCLE_D-HX

\begin{tabular}{|c|c|c|c|c|c|}
\hline \multirow{2}{*}{$\begin{array}{l}\text { Condition } \\
\text { Refrigerant }\end{array}$} & \multicolumn{5}{|c|}{ Medium Temperature } \\
\hline & R404A & R-No.682 & R-No.595 & R-No.769 & R-No.939 \\
\hline \multirow[t]{2}{*}{ Composition } & R125/R143/ & R134a/R32/ & R134a/R32/ & R134a/R32/ & R134a/R32/ \\
\hline & $\mathrm{R} 134 \mathrm{a}$ & R125/R1270 & R125/R1270 & R125/R1270 & $\mathrm{R} 125 / \mathrm{R} 1270$ \\
\hline Mass percentage & $44 / 52 / 4$ & $8 / 45 / 46 / 1$ & $7 / 46 / 46 / 1$ & $9 / 45 / 45 / 1$ & $11 / 44 / 44 / 1$ \\
\hline Boiling point $\left({ }^{\circ} \mathrm{C}\right)$ & -46.6 & -47.96 & -48.21 & -47.74 & -47.26 \\
\hline Critical Pressure (kPa) & 3728 & 4856 & 4867 & 4863 & 4859 \\
\hline Critical Temperature $\left({ }^{\circ} \mathrm{C}\right)$ & 72.1 & 72.83 & 72.6 & 73.16 & 73.71 \\
\hline ODP & 0 & 0 & 0 & 0 & 0 \\
\hline GWP & 3943 & 1995 & 1989 & 1973 & 1958 \\
\hline Class & $\mathrm{A} 1$ & $\mathrm{~A} 1$ & $\mathrm{~A} 1$ & $\mathrm{~A} 1$ & $\mathrm{~A} 1$ \\
\hline Lubricant type & POE & POE & POE & POE & POE \\
\hline$Q_{\text {evap }}(\mathrm{kJ} / \mathrm{kg})$ & 139.02 & 142.2 & 142.93 & 143.07 & 143.19 \\
\hline$Q_{\text {cond }}(\mathrm{kJ} / \mathrm{kg})$ & 198.57 & 211.55 & 212.52 & 212.8 & 213.04 \\
\hline Work (kJ/kg) & 59.55 & 69.34 & 69.59 & 69.72 & 69.84 \\
\hline $\mathrm{COPc}$ & 2.335 & 2.051 & 2.054 & 2.052 & 2.05 \\
\hline Evaporator Pressure (kPa) & 477.3 & 588.4 & 595.40 & 582.7 & 570.20 \\
\hline Condenser Pressure (kPa) & 2284.10 & 3017.60 & 3038.20 & 3001.50 & 2965.00 \\
\hline Evaporator Temp glide $\left({ }^{\circ} \mathrm{C}\right)$ & -0.5 & -1.5 & -1.3 & -1.6 & -1.9 \\
\hline Condenser Temp glide $\left({ }^{\circ} \mathrm{C}\right)$ & 0.3 & 1.4 & 1.2 & 1.5 & 1.7 \\
\hline
\end{tabular}

\section{Conclusions}

In this paper, we determined new refrigerant mixtures comprised of R134a, R32, R125, and R1270 by using refrigerant composition results of the decision tree function in the RapidMiner software, which came first in KDnuggets annual software poll. All resulting refrigerants were composed of polyol ester oil (POE), which has been classified as a Class A1, incombustible, and non-toxic refrigerant. The properties of the refrigerants were verified using the National Institute of Standards and Technology (NIST) reference fluid thermodynamic and transport properties database (REFPROP) 
software and the NIST vapor compression cycle model accounting for refrigerant thermodynamic and transport properties (CYCLE_D-HX) software, and were in accordance with the CAN/ANSI/AHRI540 standards of the Air-Conditioning, Heating, and Refrigeration Institute (AHRI). It was indicated that the normal boiling point of R-No.595 was higher than that of R404A by 4.58\%, with a higher cooling capacity and a lower GWP than those of R404A by a margin of $50.34 \%$ due to the presence of hydrofluorocarbon (HFCs) R32 and hydrocarbon (HCs) R1270. It should be emphasized that a mixedrefrigerant design must consider all relevant parameters, such as the GWP, boiling point, $\mathrm{Cp}$ liquid/vapor and liquid/vapor conductivity, refrigerant effect, heat rejection, refrigerant work, evaporator pressure, high pressure, and COPc. The proposed refrigerant mixes provide alternate refrigerant options which are composed of $1 \%$ hydrocarbon (HCs) R1270, consistent with the evolution of the fourth-generation refrigerants; which contain a mixture of HFCs, HFOs, HCs, and natural refrigerants, in order to produce a low-GWP, zero ODP, high-capacity, low-operating pressure, and non-toxic refrigerants. In the future, researchers should incorporate the use of natural refrigerants that have low cost. The problems of high evaporator pressure and high condenser pressure, which lead to high refrigerant work, can be solved by adjusting the composition of the refrigerant or mix (i.e., by using a refrigerant that operates at low pressure), thereby improving the COP of the refrigerant.

\section{Acknowledgement}

This study was supported by Prince of Songkla University and SANYO S.M.I. (Thailand) Co., Ltd.

\section{References}

[1] Kuo, Chung-Feng Jeffrey, Chieh-Hung Lin, and Ming-Hao Lee. "Analyze the energy consumption characteristics and affecting factors of Taiwan's convenience stores-using the big data mining approach." Energy and Buildings 168 (2018): 120-136. https://doi.org/10.1016/i.enbuild.2018.03.021

[2] Saengsikhiao, Piyanut, Juntakan Taweekun, Kittinan Maliwan, Somchai Sae-ung, and Thanansak Theppaya. "Investigation and Analysis of R463A as an Alternative Refrigerant to R404A with Lower Global Warming Potential." Energies 13, no. 6 (2020): 1514. https://doi.org/10.3390/en13061514

[3] Shen, Hanyan, Ke Xu, and James Freihaut. "A statistical study on energy performance of US convenience stores: Investigation of factors and bench marking on store energy use." Energy and Buildings 183 (2019): 792-802. https://doi.org/10.1016/i.enbuild.2018.10.018

[4] Tassou, S. A., Y. Ge, A. Hadawey, and Doug Marriott. "Energy consumption and conservation in food retailing." Applied Thermal Engineering 31, no. 2-3 (2011): 147-156. https://doi.org/10.1016/i.applthermaleng.2010.08.023

[5] Wang, An-Ping, and Pau-Lo Hsu. "The network-based energy management system for convenience stores." Energy and buildings 40, no. 8 (2008): 1437-1445. https://doi.org/10.1016/i.enbuild.2008.01.007

[6] Chou, Ding-chin, Ching-Shan Chang, and Yong-Zhi Hsu. "Investigation and analysis of power consumption in convenience stores in Taiwan." Energy and Buildings 133 (2016): 670-687. https://doi.org/10.1016/i.enbuild.2016.10.010

[7] Evans, J. A., E. C. Hammond, A. J. Gigiel, A. M. Fostera, L. Reinholdt, K. Fikiin, and C. Zilio. "Assessment of methods to reduce the energy consumption of food cold stores." Applied Thermal Engineering 62, no. 2 (2014): 697-705. https://doi.org/10.1016/i.applthermaleng.2013.10.023

[8] Mota-Babiloni, Adrián, Joaquín Navarro-Esbrí, Pavel Makhnatch, and Francisco Molés. "Refrigerant R32 as lower GWP working fluid in residential air conditioning systems in Europe and the USA." Renewable and Sustainable Energy Reviews 80 (2017): 1031-1042. https://doi.org/10.1016/j.rser.2017.05.216

[9] Cardoso, Bruno J., Francisco B. Lamas, Adélio R. Gaspar, and José B. Ribeiro. "Refrigerants used in the Portuguese food industry: Current status." International journal of refrigeration 83 (2017): 60-74. https://doi.org/10.1016/j.ijrefrig.2017.07.013

[10] Sánchez, D., R. Cabello, R. Llopis, J. Catalán-Gil, and L. Nebot-Andrés. "Energy assessment and environmental impact analysis of an R134a/R744 cascade refrigeration plant upgraded with the low-GWP refrigerants R152a, R1234ze (E), propane (R290) and propylene (R1270)." International Journal of Refrigeration 104 (2019): 321-334. https://doi.org/10.1016/i.ijrefrig.2019.05.028 
[11] Calleja-Anta, Daniel, Laura Nebot-Andrés, Jesús Catalán-Gil, Daniel Sánchez, Ramón Cabello, and Rodrigo Llopis. "Thermodynamic screening of alternative refrigerants for R290 and R600a." Results in Engineering 5 (2020): 100081. https://doi.org/10.1016/j.rineng.2019.100081

[12] Massuchetto, Luiz Henrique Parolin, Raiza Barcelos Corrêa do Nascimento, Stella Maia Rocha de Carvalho, Hugo Valença de Araújo, and José Vicente Hallak d'Angelo. "Thermodynamic performance evaluation of a cascade refrigeration system with mixed refrigerants: R744/R1270, R744/R717 and R744/RE170." International Journal of Refrigeration 106 (2019): 201-212. https://doi.org/10.1016/j.ijrefrig.2019.07.005

[13] Zhang, Li, Chunguang Yang, Huanying Liu, Ping Du, and Hongyan Gao. "Theoretical Investigation on the properties of R744/R290 mixtures." Procedia Engineering $205 \quad$ (2017): $1620-1626$. https://doi.org/10.1016/i.proeng.2017.10.304

[14] Mečárik, K., and M. Masaryk. "Thermodynamic properties of refrigerants R11, R12, R13, R14, R22, R23, R113, R114, R500 and R502." Heat recovery systems and CHP 11, no. 2-3 (1991): 193-197. https://doi.org/10.1016/08904332(91)90135-Q

[15] Bao, Z. Y., D. F. Fletcher, and B. S. Haynes. "Flow boiling heat transfer of Freon R11 and HCFC123 in narrow passages." International Journal of Heat and Mass Transfer 43, no. 18 (2000): 3347-3358. https://doi.org/10.1016/S0017-9310(99)00379-8

[16] Chen, Shuangtao, Jionghui Liu, Xiufang Liu, and Yu Hou. "An experimental comparison of heat transfer characteristic between R134-a and R22 in spray cooling." Experimental Thermal and Fluid Science 66 (2015): $206-212$. https://doi.org/10.1016/i.expthermflusci.2015.03.015

[17] Fatouh, M., Talaat A. Ibrahim, and A. Mostafa. "Performance assessment of a direct expansion air conditioner working with R407C as an R22 alternative." Applied Thermal Engineering 30, no. 2-3 (2010): 127-133. https://doi.org/10.1016/i.applthermaleng.2009.07.009

[18] Kuczynski, Waldemar, Tadeusz Bohdal, Josua P. Meyer, and Aleksander Denis. "A regressive model for dynamic instabilities during the condensation of R404A and R507 refrigerants." International Journal of Heat and Mass Transfer 141 (2019): 1025-1035. https://doi.org/10.1016/i.ijheatmasstransfer.2019.06.095

[19] Kuczynski, Waldemar. "Experimental research on condensation of R134a and R404A refrigerants in mini-channels during impulsive instabilities. Part I." International Journal of Heat and Mass Transfer 128 (2019): 728-738. https://doi.org/10.1016/j.ijheatmasstransfer.2018.09.045

[20] Kondou, Chieko, Shohei Umemoto, Shigeru Koyama, and Yutaka Mitooka. "Improving the heat dissipation performance of a looped thermosyphon using low-GWP volatile fluids R1234ze (Z) and R1234ze (E) with a superhydrophilic boiling surface." Applied Thermal Engineering $118 \quad$ (2017): 147-158. https://doi.org/10.1016/i.applthermaleng.2017.02.073

[21] Colombo, Luigi Pietro Maria, Andrea Lucchini, and Luca Molinaroli. "Experimental analysis of the use of R1234yf and R1234ze (E) as drop-in alternatives of R134a in a water-to-water heat pump." International Journal of Refrigeration (2020). https://doi.org/10.1016/j.ijrefrig.2020.03.004

[22] Sun, Zhili, Qi Cui, Qifan Wang, Jinghong Ning, Jianghe Guo, Baomin Dai, Yongqiang Liu, and Yibo Xu. "Experimental study on CO2/R32 blends in a water-to-water heat pump system." Applied Thermal Engineering 162 (2019): 114303. https://doi.org/10.1016/j.applthermaleng.2019.114303

[23] Hu, Xiaozhen, Tao Yang, Xianyang Meng, and Jiangtao Wu. "Isothermal vapor liquid equilibrium measurements for difluoromethane (R32)+ fluoroethane (R161)+ trans-1, 3, 3, 3-tetrafluoropropene (R1234ze (E)) ternary mixtures." International Journal of Refrigeration 79 (2017): 49-56. https://doi.org/10.1016/j.ijrefrig.2017.04.019

[24] Ju, Fujun, Xiaowei Fan, Yaping Chen, Honglin Zhang, Tuanjie Wang, and Xiangyang Tang. "Performance assessment of heat pump water heaters with R1233zd (E)/HCs binary mixtures." Applied Thermal Engineering 123 (2017): 13451355. https://doi.org/10.1016/i.applthermaleng.2017.05.137

[25] Longo, Giovanni A., Simone Mancin, Giulia Righetti, Claudio Zilio, and J. Steven Brown. "Assessment of the lowGWP refrigerants R600a, R1234ze (Z) and R1233zd (E) for heat pump and organic Rankine cycle applications." Applied Thermal Engineering 167 (2020): 114804. https://doi.org/10.1016/i.applthermaleng.2019.114804

[26] Zhu, Jingwei, and Stefan Elbel. "Experimental investigation into the influence of vortex control on transcritical R744 ejector and cycle performance." Applied Thermal Engineering 164 (2020): 114418. https://doi.org/10.1016/j.applthermaleng.2019.114418

[27] Zhang, Yao, Xiaopo Wang, and Jiajia Yin. "Viscosity of saturated mixtures of 1-hexyl-3-methyl-imidazolium bis (trifluoromethylsulfonyl) amide with R600a and R152a." The Journal of Chemical Thermodynamics 141 (2020): 105970. https://doi.org/10.1016/i.jct.2019.105970

[28] Longo, Giovanni A., Giulia Righetti, and Claudio Zilio. "Heat-transfer assessment of the low GWP substitutes for traditional HFC refrigerants." International Journal of Heat and Mass Transfer 139 (2019): 31-38. https://doi.org/10.1016/i.ijheatmasstransfer.2019.04.144 
[29] Shaik, Sharmas Vali, and TP Ashok Babu. "Theoretical computation of performance of sustainable energy efficient R22 alternatives for residential air conditioners." Energy Procedia 138 (2017): 710-716. https://doi.org/10.1016/j.egypro.2017.10.205

[30] La Rocca, Vincenzo, and Giuseppe Panno. "Experimental performance evaluation of a vapour compression refrigerating plant when replacing R22 with alternative refrigerants." Applied energy 88, no. 8 (2011): 2809-2815. https://doi.org/10.1016/i.apenergy.2011.01.051

[31] Kasera, Shailendra, and Shishir Chandra Bhaduri. "Performance of R407C as an Alternate to R22: A Review." Energy Procedia 109 (2017): 4-10. https://doi.org/10.1016/i.egypro.2017.03.032

[32] Elgendy, E., M. Melike, and M. Fatouh. "Experimental assessment of a split air conditioner working with R-417A under different indoor and outdoor conditions." International Journal of Refrigeration 85 (2018): 268-281. https://doi.org/10.1016/i.ijrefrig.2017.10.005

[33] Fernandez-Seara, Jose, Francisco J. Uhia, Ruben Diz, and J. Alberto Dopazo. "Vapour condensation of R22 retrofit substitutes R417A, R422A and R422D on CuNi turbo C tubes." International journal of refrigeration 33, no. 1 (2010): 148-157. https://doi.org/10.1016/i.ijrefrig.2009.09.006

[34] Aprea, Ciro, and Angelo Maiorino. "An experimental investigation of the global environmental impact of the R22 retrofit with R422D." Energy 36, no. 2 (2011): 1161-1170. https://doi.org/10.1016/i.energy.2010.11.032

[35] Oruc, Vedat, and Atilla G. Devecioğlu. "Thermodynamic performance of air conditioners working with R417A and R424A as alternatives to R22." International journal of refrigeration 55 (2015): 120-128. https://doi.org/10.1016/i.ijrefrig.2015.03.021

[36] Chen, Xiaoning, Cichong Liu, Jingye Yang, and Jiangping Chen. "Experimental study on R-22, R-427A, R-161 and R290 in air-source heat pump for space heating at low ambient temperatures." International Journal of Refrigeration 96 (2018): 147-154. https://doi.org/10.1016/i.ijrefrig.2018.08.021

[37] Devecioğlu, Atilla G., and Vedat Oruç. "The influence of plate-type heat exchanger on energy efficiency and environmental effects of the air-conditioners using R453A as a substitute for R22." Applied Thermal Engineering 112 (2017): 1364-1372. https://doi.org/10.1016/i.applthermaleng.2016.10.180

[38] Yang, Meng, Hua Zhang, Zhaofeng Meng, and Yanbin Qin. "Experimental study on R1234yf/R134a mixture (R513A) as R134a replacement in a domestic refrigerator." Applied Thermal Engineering 146 (2019): 540-547. https://doi.org/10.1016/i.applthermaleng.2018.09.122

[39] Makhnatch, Pavel, Adrián Mota-Babiloni, Alejandro López-Belchí, and Rahmatollah Khodabandeh. "R450A and R513A as lower GWP mixtures for high ambient temperature countries: Experimental comparison with R134a." Energy 166 (2019): 223-235. https://doi.org/10.1016/j.energy.2018.09.001

[40] Heredia-Aricapa, Y., J. M. Belman-Flores, Adrián Mota-Babiloni, Juan Serrano-Arellano, and Juan J. García-Pabón. "Overview of low GWP mixtures for the replacement of HFC refrigerants: R134a, R404A and R410A." International Journal of Refrigeration 111 (2020): 113-123. https://doi.org/10.1016/j.ijrefrig.2019.11.012

[41] Yousif, Qais Abid, Normah Mohd-Ghazali, Agus Sunjarianto Pamitran, and Yushazaziah Mohd-Yunos. "Optimized Condition for Pairing of Different Friction Factor and Viscosity Equations for the Frictional Pressure Drop of R22 and R290." International Journal of Air-Conditioning and Refrigeration (2019): 1950037. https://doi.org/10.1142/S2010132519500378

[42] Zhang, Xiaoyan. "Heat transfer and enhancement analyses of flow boiling for R417A and R22." Experimental thermal and fluid science 35, no. 7 (2011): 1334-1342. https://doi.org/10.1016/i.expthermflusci.2011.04.020

[43] Llopis, R., E. Torrella, R. Cabello, and D. Sánchez. "HCFC-22 replacement with drop-in and retrofit HFC refrigerants in a two-stage refrigeration plant for low temperature." International journal of refrigeration 35, no. 4 (2012): 810 816. https://doi.org/10.1016/j.ijrefrig.2012.01.001

[44] Oruç, Vedat, Atilla G. Devecioğlu, Uğur Berk, and Ibrahim Vural. "Experimental comparison of the energy parameters of HFCs used as alternatives to HCFC-22 in split type air conditioners." International Journal of Refrigeration 63 (2016): 125-132. https://doi.org/10.1016/j.ijrefrig.2015.11.004

[45] Wang, Fang, Fengkun Wang, Xiaowei Fan, and Zhiwei Lian. "Experimental study on an inverter heat pump with HFC125 operating near the refrigerant critical point." Applied thermal engineering 39 (2012): 1-7. https://doi.org/10.1016/i.applthermaleng.2012.01.016

[46] Arora, Akhilesh, and H. L. Sachdev. "Thermodynamic analysis of R422 series refrigerants as alternative refrigerants to HCFC22 in a vapour compression refrigeration system." International journal of energy research 33, no. 8 (2009): 753-765. https://doi.org/10.1002/er.1508

[47] Saeed, Mian Umar, Shafiq R. Qureshi, Khurram J. Hashmi, Muhammad A. Khan, and Syed N. Danish. "Performance assessment of alternate refrigerants for retrofitting R22 based air conditioning system." Thermal Science 22, no. 2 (2018): 931-941. https://doi.org/10.2298/TSCI160811315S 
[48] Devecioglu, Atilla G., and Vedat Oruc. "The experimental comparison of environmental impacts of some HFC's used instead of HCFC-22." Isi Bilimi Ve Teknigi Dergisi-Journal of Thermal Science and Technology 36, no. 1 (2016): 99105.

[49] Paradeshi, Lokesh, M. Srinivas, and S. Jayaraj. "Performance studies of R433A in a direct expansion solar-assisted heat pump." International Journal of Ambient Energy 41, no. 3 (2020): $262-273$. https://doi.org/10.1080/01430750.2018.1451369

[50] Subiantoro, A., K. T. Ooi, and A. Z. Junaidi. "Performance and suitabilitycomparisons of some R22 possible substitute refrigerants." In 8thInternational Conference on Compressors and their Systems, pp. 67-76. 2013. https://doi.org/10.1533/9781782421702.2.67

[51] Hari Sankar, R.; Basnth, S.; Ajay Ghosh, K. J.; Sivan, M.; Vyshak Dileep, K. "Research on environment friendly alternatives for R22, R12 and R409A refrigerants." International Journal of Recent Technology and Engineering 8, no. 4 (2019): 265-271.

[52] Oruç, Vedat, Atilla G. Devecioğlu, and Sertaç Ender. "Improvement of energy parameters using R442A and R453A in a refrigeration system operating with R404A." Applied Thermal Engineering 129 (2018): $243-249$. https://doi.org/10.1016/j.applthermaleng.2017.10.035

[53] Ma, Zhenxi, Fengguo Liu, Changfei Tian, Leilei Jia, and Wei Wu. "Experimental comparisons on a gas engine heat pump using R134a and low-GWP refrigerant R152a." International Journal of Refrigeration (2020). https://doi.org/10.1016/j.ijrefrig.2020.03.007

[54] Jacob, Tabeel A., Ethan P. Matty, and Brian M. Fronk. "Experimental investigation of in-tube condensation of low GWP refrigerant R450A using a fiber optic distributed temperature sensor." International Journal of Refrigeration 103 (2019): 274-286. https://doi.org/10.1016/i.ijrefrig.2019.04.021

[55] Sun, Jian, Wenhua Li, and Borui Cui. "Energy and exergy analyses of R513a as a R134a drop-in replacement in a vapor compression refrigeration system." International Journal of Refrigeration 112 (2020): 348-356. https://doi.org/10.1016/j.ijrefrig.2019.12.014

[56] Mota-Babiloni, Adrián, Joaquín Navarro-Esbrí, Bernardo Peris, Francisco Molés, and Gumersindo Verdú. "Experimental evaluation of R448A as R404A lower-GWP alternative in refrigeration systems." Energy Conversion and Management 105 (2015): 756-762. https://doi.org/10.1016/i.enconman.2015.08.034

[57] Hu, Xinhao, Zhongbin Zhang, Yuchen Yao, and Qing Wang. "Non-azeotropic refrigerant charge optimization for cold storage unit based on year-round performance evaluation." Applied Thermal Engineering 139 (2018): 395-401. https://doi.org/10.1016/i.applthermaleng.2018.04.089

[58] Bortolini, Marco, Mauro Gamberi, Rita Gamberini, Alessandro Graziani, Francesco Lolli, and Alberto Regattieri. "Retrofitting of R404a commercial refrigeration systems using R410a and R407f refrigerants." International journal of refrigeration 55 (2015): 142-152. https://doi.org/10.1016/j.ijrefrig.2015.02.015

[59] Mota-Babiloni, Adrián, Pavel Makhnatch, and Rahmatollah Khodabandeh. "Recent investigations in HFCs substitution with lower GWP synthetic alternatives: Focus on energetic performance and environmental impact." International Journal of Refrigeration 82 (2017): 288-301. https://doi.org/10.1016/j.jjrefrig.2017.06.026

[60] Mancin, Simone, Davide Del Col, and Luisa Rossetto. "Partial condensation of R407C and R410A refrigerants inside a plate heat exchanger." Experimental thermal and fluid science 36 (2012): $149-157$. https://doi.org/10.1016/j.expthermflusci.2011.09.007

[61] Mendoza-Miranda, Juan Manuel, Adrián Mota-Babiloni, and Joaquín Navarro-Esbrí. "Evaluation of R448A and R450A as low-GWP alternatives for R404A and R134a using a micro-fin tube evaporator model." Applied Thermal Engineering 98 (2016): 330-339. https://doi.org/10.1016/j.applthermaleng.2015.12.064

[62] Makhnatch, Pavel, Adrián Mota-Babiloni, Jörgen Rogstam, and Rahmatollah Khodabandeh. "Retrofit of lower GWP alternative R449A into an existing R404A indirect supermarket refrigeration system." International Journal of Refrigeration 76 (2017): 184-192. https://doi.org/10.1016/j.ijrefrig.2017.02.009

[63] Górny, Kasper, Arkadiusz Stachowiak, Przemysław Tyczewski, and Wiesław Zwierzycki. "Lubricity of selected oils in mixtures with the refrigerants R452A, R404A, and R600a." Tribology International 134 (2019): 50-59. https://doi.org/10.1016/j.triboint.2018.12.033

[64] Devecioğlu, Atilla G., and Vedat Oruç. "An analysis on the comparison of low-GWP refrigerants to alternatively use in mobile air-conditioning systems." Thermal Science and Engineering Progress 1 (2017): 1-5. https://doi.org/10.1016/j.tsep.2017.02.002

[65] Mota-Babiloni, Adrián, Jorge Haro-Ortuno, Joaquín Navarro-Esbrí, and Ángel Barragán-Cervera. "Experimental drop-in replacement of R404A for warm countries using the low GWP mixtures R454C and R455A." International Journal of Refrigeration 91 (2018): 136-145. https://doi.org/10.1016/i.ijrefrig.2018.05.018

[66] Wang, Dong, Yaru Liu, Zunli Kou, Lifang Yao, Yuehong Lu, Leren Tao, and Peng Xia. "Energy and exergy analysis of an air-source heat pump water heater system using CO2/R170 mixture as an azeotropy refrigerant for sustainable 
development." International Journal of $\quad$ Refrigeration $106 \quad$ (2019): 628-638. https://doi.org/10.1016/i.ijrefrig.2019.03.007

[67] Fajar, TK Berkah, P. Restu Bagas, S. Ukhi, M. I. Alhamid, and Arnas Lubis. "Energy and exergy analysis of an R410A small vapor compression system retrofitted with R290." Case Studies in Thermal Engineering (2020): 100671. https://doi.org/10.1016/j.csite.2020.100671

[68] Yang, Lixiang, Maoqiong Gong, Hao Guo, Xueqiang Dong, Jun Shen, and Jianfeng Wu. "Isothermal (vapour+ liquid) equilibrium measurements and correlation for the $\{\mathrm{n}$-butane (R600)+ 1, 1, 1, 3, 3-pentafluoropropane (R245fa)\} system at temperatures from (303.150 to 373.150) K." The Journal of Chemical Thermodynamics 95 (2016): 49-53. https://doi.org/10.1016/i.jct.2015.11.021

[69] Qiu, Jinyou, and Hua Zhang. "Experimental investigation on two-phase frictional pressure drop of R600a and R600a/3GS oil mixture in a smooth horizontal tube." International Journal of Refrigeration (2020). https://doi.org/10.1016/i.ijrefrig.2020.04.025

[70] Pratama, Felix, Nadhilah Reyseliani, Ahmad Syauqi, Yunus Daud, Widodo Wahyu Purwanto, Praswasti PDK Wulan, and Akhmad Hidayatno. "Thermoeconomic assessment and optimization of wells to flash-binary cycle using pure R601 and zeotropic mixtures in the Sibayak geothermal field." Geothermics 85 (2020): 101778. https://doi.org/10.1016/i.geothermics.2019.101778

[71] Li, Jian, Qiang Liu, Yuanyuan Duan, and Zhen Yang. "Performance analysis of organic Rankine cycles using R600/R601a mixtures with liquid-separated condensation." Applied Energy 190 (2017): 376-389. https://doi.org/10.1016/i.apenergy.2016.12.131

[72] Wu, Xi, Zhao Yang, Xiaoming Wang, and Yulong Lin. "Experimental and theoretical study on the influence of temperature and humidity on the flammability limits of ethylene (R1150)." Energy 52 (2013): 185-191. https://doi.org/10.1016/i.energy.2013.01.042

[73] Zhang, Yeqiang, Yongning He, Yanling Wang, Xuehong Wu, Mingzheng Jia, and Yi Gong. "Experimental investigation of the performance of an R1270/CO2 cascade refrigerant system." International Journal of Refrigeration (2020). https://doi.org/10.1016/j.ijrefrig.2020.02.017

[74] CAN/ANSI/AHRI540 Performance Rating of Positive Displacement Refrigerant Compressors and Compressor Units. Air-Conditioning, Heating, and Refrigeration Institute (AHRI) (E) 2015, 5.

[75] Aprea, Ciro, Angelo Maiorino, and Rita Mastrullo. "Change in energy performance as a result of a R422D retrofit: An experimental analysis for a vapor compression refrigeration plant for a walk-in cooler." Applied energy 88, no. 12 (2011): 4742-4748. https://doi.org/10.1016/i.apenergy.2011.06.049

[76] Lumpkin, Domenique R., Ammar M. Bahman, and Eckhard A. Groll. "Two-phase injected and vapor-injected compression: Experimental results and mapping correlation for a R-407C scroll compressor." International Journal of Refrigeration 86 (2018): 449-462. https://doi.org/10.1016/j.ijrefrig.2017.11.009

[77] Lausch, Angela, Andreas Schmidt, and Lutz Tischendorf. "Data mining and linked open data-New perspectives for data analysis in environmental research." Ecological Modelling 295 (2015): 5-17. https://doi.org/10.1016/j.ecolmodel.2014.09.018

[78] Bell, lan H., Piotr A. Domanski, Mark O. McLinden, and Gregory T. Linteris. "The hunt for nonflammable refrigerant blends to replace R-134a." International Journal of Refrigeration 104 (2019): $484-495$. https://doi.org/10.1016/j.ijrefrig.2019.05.035

[79] Domanski, Piotr A., Riccardo Brignoli, J. Steven Brown, Andrei F. Kazakov, and Mark O. McLinden. "Low-GWP refrigerants for medium and high-pressure applications." International Journal of Refrigeration 84 (2017): $198-209$. https://doi.org/10.1016/i.ijrefrig.2017.08.019

[80] Brignoli, Riccardo, J. Steven Brown, Harrison M. Skye, and Piotr A. Domanski. "Refrigerant performance evaluation including effects of transport properties and optimized heat exchangers." International Journal of Refrigeration 80 (2017): 52-65. https://doi.org/10.1016/j.ijrefrig.2017.05.014

[81] Saengsikhiao, Piyanut, Juntakan Taweekun, Kittinan Maliwan, Somchai Sae-ung, and Thanansak Theppaya. "The Improvement of Energy Efficiency for Refrigeration System in Thailand Convenience Store by Digital Scroll Compressor." Journal of Advanced Research in Fluid Mechanics and Thermal Sciences 74, n0. 1 (2020): $144-150$. https://doi.org/10.37934/arfmts.74.1.144150

[82] Saengsikhiao, Piyanut, Juntakan Taweekun, Kittinan Maliwan, Somchai Sae-ung, and Thanansak Theppaya. "The Replacement of the R404A Refrigeration System with The Environmentally Friendly R448A, to Improve Convenience Store Energy Efficiency in Thailand." Journal of Advanced Research in Fluid Mechanics and Thermal Sciences 75, no. 1 (2020): 137-146. https://doi.org/10.37934/arfmts.75.1.137146

[83] Saengsikhiao, Piyanut, Juntakan Taweekun, Kittinan Maliwan, Somchai Sae-ung, and Thanansak Theppaya. "The Performance Simulation of The New R463A HFC/HFO/Carbon Dioxide Refrigerant with Lower GWP, As an Alternate Option for The R404A Refrigeration System." Journal of Advanced Research in Fluid Mechanics and Thermal Sciences 76, no. 1 (2020): 113-123. https://doi.org/10.37934/arfmts.76.1.113123 
[84] Saengsikhiao, Piyanut, Juntakan Taweekun, Kittinan Maliwan, Somchai Sae-ung, and Thanansak Theppaya. "Development of Environmentally Friendly and Energy Efficient Refrigerants for Refrigeration Systems." Energy Engineering: Journal of the Association of Energy Engineering 118, no. 2 (2021): $411-433$. https://doi.org/10.32604/EE.2021.012860

[85] Saengsikhiao, Piyanut, Juntakan Taweekun, Kittinan Maliwan, Somchai Sae-ung, and Thanansak Theppaya. "Improving Energy Efficiency in the Supermarket by Retrofitting Low E Glass Doors for Open Refrigerated." Journal of Advanced Research in Applied Sciences and Engineering Technology 20, no. 1 (2020): 11-17. https://doi.org/10.37934/araset.20.1.1117

[86] Saengsikhiao, Piyanut, Juntakan Taweekun, Kittinan Maliwan, Somchai Sae-ung, and Thanansak Theppaya. "The Green Logistics Idea Using Vacuum Insulation Panels (VIPs) For Freezer Logistics Box in Normal Truck." Journal of Advanced Research in Applied Sciences and Engineering Technology 21, no. 1 (2020): 15-21. https://doi.org/10.37934/araset.21.1.1521

[87] Saengsikhiao, Piyanut, Juntakan Taweekun, Kittinan Maliwan, Somchai Sae-ung, and Thanansak Theppaya. "Development of Environmentally-Friendly and Energy Efficient Refrigerant for Medium Temperature Refrigeration Systems." Journal of Advanced Research in Materials Science 71, no. 1 (2020): 12-31. https://doi.org/10.37934/arms.71.1.1231

[88] Saengsikhiao, Piyanut, and Juntakan Taweekun. "Improving Energy Efficiency in Supermarkets by Retrofitting LowE Glass Doors for Open Refrigeration Systems with Digital Semi Hermetic Compressor." Journal of Advanced Research in Fluid Mechanics and Thermal Sciences 82, no. 1 (2021): $145-157$. https://doi.org/10.37934/arfmts.82.1.145157

[89] Sidik, NA Che, and O. Adnan Alawi. "Computational investigations on heat transfer enhancement using nanorefrigerants." J. Adv. Res. Des. 1, no. 1 (2014): 35-41. 